\title{
Update on Human Rhinovirus and Coronavirus Infections
}

\author{
Stephen B. Greenberg, MD ${ }^{1}$ \\ ${ }^{1}$ Department of Medicine, Ben Taub Hospital, Baylor College of \\ Medicine, Houston, Texas
}

Semin Respir Crit Care Med 2016;37:555-571.
Address for correspondence Stephen B. Greenberg, MD, Department of Medicine, Ben Taub Hospital, Baylor College of Medicine, One Baylor Plaza, MS285, Houston, TX 77030 (e-mail: stepheng@bcm.edu).

\begin{abstract}
Keywords

- human rhinovirus

- human coronavirus

- polymerase chain reaction
\end{abstract}

Human rhinovirus (HRV) and coronavirus (HCoV) infections are associated with both upper respiratory tract illness ("the common cold") and lower respiratory tract illness (pneumonia). New species of HRVs and HCoVs have been diagnosed in the past decade. More sensitive diagnostic tests such as reverse transcription-polymerase chain reaction have expanded our understanding of the role these viruses play in both immunocompetent and immunosuppressed hosts. Recent identification of severe acute respiratory syndrome and Middle East respiratory syndrome viruses causing serious respiratory illnesses has led to renewed efforts for vaccine development. The role these viruses play in patients with chronic lung disease such as asthma makes the search for antiviral agents of increased importance.
More than $50 \%$ of all common colds are caused by human rhinoviruses (HRVs) and coronaviruses (HCoVs). ${ }^{1-3}$ The common cold includes rhinitis and pharyngitis, as well as sneezing, hoarseness, and cough. ${ }^{4,5}$ The illness is usually selflimited in healthy people, but can be associated with complications in individuals who suffer from heart or lung disease, or who are immunosuppressed. ${ }^{6-11}$ As a frequent cause of the common cold, these viruses are responsible for millions of lost work days, school absenteeism, and physician visits. In infants and young children, these viruses are associated with many cases of acute otitis media (AOM) and rhinosinusitis. ${ }^{12}$ Newer more sensitive diagnostic tests have increased the percentage of respiratory illnesses attributable to these viruses. ${ }^{13-15}$ Most HRV infections are symptomatic, but asymptomatic virus shedding has been reported with increasing frequency.

In the past 10 years, several new HRVs and HCoVs have been identified. ${ }^{16-18}$ In addition, recent studies have provided a better understanding of the pathogenesis of these viral infections which could lead to more specific treatments. This review will update recent advances in our knowledge of these two virus groups and their importance in respiratory viral infections.

\section{Rhinoviruses}

\section{Virology}

HRVs are positive-sense, single-stranded ribonucleic acid (RNA) viruses with icosahedral symmetry. The capsid is composed of four proteins: VP1, VP2, VP3, and VP4., ${ }^{49}$ VP4 is on the inside of the virus and anchors the RNA core to the viral capsid. The complete sequencing of all known HRV genomes has been reported. ${ }^{20}$

More than 150 serotypes of HRVs have been identified. Most of the HRV serotypes of the HRV-A and HRV-B families use intercellular adhesion molecule-1 (ICAM-1; major group) as the cell receptor for the virus entry. A few HRVs used heparin sulfate proteoglycan as an additional receptor and approximately 10 serotypes use low-density lipoprotein as the cell receptor (minor group). In 2002, a new clade of HRVs was reported and labeled HRV-C. ${ }^{19}$ Although HRV-C strains have been characterized by genome sequencing, the receptor used to infect epithelial cells is currently unidentified.

During replication, the RNA genome serves as an mRNA, which encodes the capsid or structural proteins, as well as the nonstructural proteins. ${ }^{4}$ After cell entry, the viral genome is translated into a polyprotein, which undergoes proteolytic cleavage to produce the structural and nonstructural gene
Issue Theme Respiratory Viral Infections; Guest Editor: Sunit K. Singh, PhD
Copyright $\odot 2016$ by Thieme Medical Publishers, Inc., 333 Seventh Avenue, New York, NY 10001, USA. Tel: +1(212) 584-4662.
DOI http://dx.doi.org/ 10.1055/s-0036-1584797. ISSN 1069-3424. 
products. Serotypes of HRVs are based on amino acid differences in the four capsid proteins.

Enteroviruses (EVs) are not typically thought of as causing acute respiratory tract infections. However, EV68 has properties of both EVs and HRVs, and has been independently identified as HRV serotype 87. ${ }^{21}$ EV68 and EV104 have been associated with respiratory illness in multiple countries. ${ }^{22-26}$

\section{Pathogenesis}

HRV infections initially involve the upper respiratory tract. After deposition of HRV in the eye or nose, the virus attaches to host cell epithelium. Infection of nasal epithelial cells results in increased neutrophils detectable in the nasal mucosa and secretions with release of inflammatory mediators. Although HRVs replicate best at $33^{\circ} \mathrm{C}$, they have been found in lower respiratory tract cells where the temperature is $37^{\circ} \mathrm{C}$.

HRVS do not produce cytopathologic changes; however, HRVs appear to disrupt tight junctions between cells, leading to increased vascular leakage and mucus secretion. Using primary nasal epithelial cells, HRV was found to alter the function and the expression of cystic fibrosis transmembrane conductance regulator (CFTR), $\alpha$-epithelial sodium channel $(\alpha-E N a C), \beta$-epithelial sodium channel $(\beta-E N a C)$, and $\gamma$-epithelial sodium channel $(\gamma-\mathrm{ENaC}){ }^{27}$ These findings may help explain the mechanism by which altered mucociliary clearance is associated with HRV infections.

Most of the symptoms following HRV infection can be ascribed to the host response to the virus, including those mediated by the innate, mucosal, and cellular immune systems. Following epithelial cell attachment and internalization, HRV infection results in cytokine expression, including type I and type III interferons (IFNs), interleukin (IL)-6, IL-11, IL-12, IL-15, and IL-1B. ${ }^{28-32}$ Neutrophil recruitment results from release of growth factors and chemokines.

VP-I binds to ICAM-1 and is the major target for the memory immune response, residing in IgG1 subclass and IgA class antibodies. The majority of VP-1-specific antibodies are directed against an N-terminal 20-mer peptide (Pla), which is located inside the capsid. The antibody response to HRV in humans appears to be misdirected against a nonneutralizing epitope that is exposed during uncoating.

In a group of children with asthma and upper respiratory infections (URIs), type III IFN- $\lambda$ levels were significantly higher in wheezing children infected with HRV compared with non-wheezing children. ${ }^{33}$ Although type III IFN- $\lambda$ levels were lower at baseline in children with asthma compared with healthy children, they were found to be hyperexpressed during asthma exacerbation. In addition, a study reported that IFN- $\lambda$ has antiviral and anti-inflammatory properties in primary epithelial cells from asthmatic patients exposed to rhinovirus. $^{34}$

In a recently published mouse model of HRV infection, adult mice had an enhanced type 2 immune response and attenuated type 1 response compared with neonatal mice. ${ }^{35}$ The authors reported long-term mucosal metaplasia and airway responsiveness in HRV-infected neonatal mice. In addition, they found increased expression of epithelial
IL-25 with neonatal rhinovirus infection. IL-25 appears to mediate metaplasia and airway hyper-responsiveness in the HRV-infected neonatal mice. Induction of type 1 cytokines, IFN- $\gamma$, IL-12p40, and tumor necrosis factor- $\alpha$ was diminished in neonates compared with adult mice. HRV infection elicits an increased ILC2 response in neonatal mice. These observations may help our understanding of the intersection of early HRV infections and subsequent development of asthma.

\section{Epidemiology}

HRVs cause respiratory illnesses throughout the world, in all age groups, and throughout the year, although most prevalent in the fall and spring in temperate climates. ${ }^{36}$ In one study, HRVs accounted for approximately 50\% of common colds. ${ }^{37}$ HRVs commonly infect children in early childhood and into adulthood. School-aged children frequently introduce HRV infections into the home. Secondary attack rates range from 25 to $70 \%$. Day-care centers and schools are also important locations for the spread of HRV. HRV transmission can occur by close contact, autoinoculation, fomites, or aerosols.

Clinical outcomes appear to be similar between the HRV species. The recently identified HRV-C infections can have symptoms of the common cold, pharyngitis, croup, AOM, bronchiolitis, and/or pneumonia. ${ }^{38-40}$ These infections have been reported in healthy children and adults, as well as in those with asthma, immunocompromised conditions, CF, or multiple sclerosis. ${ }^{41-45}$

HRV-Cs, more than HRV-As and -Bs, are major causes of wheezing in infants and of asthma exacerbations in older children. ${ }^{46}$ of all viruses detected from middle ear fluids in children with otitis media, HRV-Cs accounted for half of the documented infections. ${ }^{47}$ Although reported infections have come mainly from respiratory tract specimens, HRV-Cs have been rarely reported in blood and pericardium. ${ }^{48,49}$

With more sensitive polymerase chain reaction (PCR) methods for HRV detection, several reports of long periods (>2-3 weeks) of HRV positivity have been published. ${ }^{50,51}$ Where strain typing has been used, however, HRV shedding normally stops within 11 to 21 days. Therefore, persistence may represent serial or overlapping infections by multiple untyped strains. $^{52}$ In immunocompromised children, HRV-C strains were detected threefold longer ( 53 vs. 16 days) than in immunocompetent children. ${ }^{53}$

Recent studies have documented HRV species in all months of the year in tropical, subtropical, and semi-arid regions. ${ }^{54,55}$ Many HRV-C strains have been found to circulate during a single year and may be detected in subsequent years. $^{56}$

\section{Diagnosis}

Standard tissue culture methods for isolation are useful for detecting HRV infection but are not very sensitive. With the development of PCR techniques, the ability to detect respiratory viruses has increased significantly. Detection of HRVs in respiratory specimens was enhanced by reverse transcription-PCR (RT-PCR), involving the use of hybridization probes or double-stranded DNA binding dye. Several studies have 
found an increased sensitivity of RT-PCR compared with viral culture techniques. $^{57-61}$

Antibody assays are reported for HRVs, but are not readily available or helpful clinically. Since there is no common antigen for HRVs, serotype-specific neutralizing antibody assays are necessary to detect rises in serum antibodies following acute infections, but the large number of HRV serotypes makes this approach impractical.

\section{Clinical Features}

The incubation period for the common cold is 12 to 72 hours. Rhinorrhea and sneezing plus nasal congestion are usually the initial symptoms. ${ }^{62,63}$ Sore throat is common and may be an early symptom. Fever is unusual. Headache and malaise are often mild. Resolution of symptoms occurs in almost all cases within 4 to 9 days.

With the use of PCR techniques, HRVs have been reported commonly in asymptomatic children. ${ }^{3}$ This may be a result of prolonged shedding from a previous respiratory illness, a mild illness that went unrecognized, or a new virus infection during the incubation period. Asymptomatic HRV shedding is not as common in adults as it appears to be in children. In addition, coinfections with other respiratory viruses during respiratory illnesses are well described. ${ }^{64-71}$

With the global spread of influenza A (H1N1) in 2009, a series of surveillance protocols were activated to monitor and characterize the pandemic. Many countries have reported on their findings in patients with influenza-like illnesses (ILI) who had respiratory specimens tested for a wide range of respiratory viruses. Most of the reports used PCR techniques in children or adults ( - Table 1 ) ${ }^{70,72-86}$ The percentage of specimens that were positive with HRV ranged from 6.3 to
40.6\%. In all the studies, the influenza illnesses could not be distinguished from HRV-related illnesses by clinical characteristics. During influenza outbreaks, other respiratory viruses, and especially HRV, continue to cause significant cases of URIs and lower respiratory infections (LRIs).

\section{Asthma and HRV Infections}

Asthma exacerbations in children and adults are frequently associated with respiratory virus infections, especially HRVs. ${ }^{87-90}$ HRV infections lead to more severe and longerlasting lower respiratory tract symptoms. ${ }^{90}$

Lower airway dysfunction following HRV infection may result from direct infection of the lower airway or by stimulating inflammatory, immunologic, or neurogenic mechanisms in the upper airway, thereby impacting the lower airways. HRV has been detected in the columnar and basal cell layers of the lower airways. ${ }^{91}$ Using in situ hybridization, the replicative strand of HRV in the lower airways has been detected. $^{92}$

Experimental HRV infections in asthmatic subjects have demonstrated airway narrowing, markers of eosinophil activation, bronchial infiltration with eosinophils, CD4 cells and CD8 cells, activation of prostaglandin and leukotriene pathways, and induction of nitric oxide. ${ }^{93-95}$ Innate immune responses were found to be defective in bronchial epithelial cells obtained from asthmatic subjects. Impaired Th1 responses to HRV were found in peripheral blood mononuclear cells, as reflected by significantly lower levels of IFN- $\alpha$ and IL-12, and higher levels of IL-10 from asthmatic patients compared with normal healthy volunteers. ${ }^{96}$

Several studies have found deficient induction of IFN- $\lambda$ by HRV in bronchial epithelial cells from asthmatic patients. ${ }^{97}$

Table1 HRV isolates from patients with influenza-like illness

\begin{tabular}{|c|c|c|c|c|}
\hline Reference & Location & Specimen & Age group & Positive for HRV (\%) \\
\hline Hombrouck et al ${ }^{72}$ & Belgium & NP & Children & 13 \\
\hline Schnepf et al $^{73}$ & France & NS & Children and adults & 20 \\
\hline Memish et $\mathrm{al}^{74}$ & Saudi Arabia & NP/TS & Adults (health care workers) & 21 \\
\hline Pascalis et $\mathrm{al}^{75}$ & Reunion Island & NS & Children and adults & 13.4 \\
\hline${\text { Chang et } \text { al }^{76}}$ & Texas & NP & Children & 29.8 \\
\hline Thiberville et $\mathrm{al}^{77}$ & Vietnam & NS & Children and adults & 20.3 \\
\hline Yang et al $^{78}$ & China & NP/TS & Adults & 6.3 \\
\hline Nisii et al ${ }^{79}$ & Italy & NP & Adults & 10 \\
\hline Kraft et al ${ }^{80}$ & United States/CDC & $?$ & Immunocompromised adults & 12.6 \\
\hline Delangue et $\mathrm{al}^{81}$ & Bolivia & NP & Children and adults & 8 \\
\hline Dia et $\mathrm{al}^{82}$ & Senegal & NP & Adults older than 50 years & 17.2 \\
\hline Ju et $\mathrm{al}^{83}$ & China & NP/TS & Children and adults & 7.5 \\
\hline Marcone et al $^{84}$ & Argentina & NP & Children & 40.6 \\
\hline Pariani et al ${ }^{85}$ & Italy & $\mathrm{NS} / \mathrm{BAL}$ & Children and adults & 9 \\
\hline Gilca et al $^{70}$ & Canada & NS & Adults & 7 \\
\hline Zimmerman et al ${ }^{86}$ & United States & NS & Children and adults & 15.4 \\
\hline
\end{tabular}

Abbreviations: HRV, human rhinovirus; NP, nasopharyngeal swab; NS, nasal swab; TS, throat swab. 
Induction of IFN- $\lambda 1$ and IFN- $\lambda 2 / 3$ mRNAs was significantly reduced in asthmatic compared with nonasthmatic subjects. Bronchoalveolar cells in asthma patients were deficient in IFN- $\lambda$ after HRV was added. These studies support the view that innate immune responses in asthmatic subjects have deficiencies in two IFN families, in several lung cell types, and in response to HRV infection.

HRV infections are a major cause of wheezing episodes in infants and children. ${ }^{98-100}$ Wheezing episodes in infancy that are virus induced are often associated with asthma development in children. HRV infections that resulted in hospitalization during infancy were recently implicated as early predictors of subsequent development of asthma. ${ }^{101,102} \mathrm{Al}-$ most $90 \%$ of wheezing children in year 3 of the study had asthma diagnosed by 6 years of age. Outpatient HRV wheezing illnesses during infancy were also found to be predictors of wheezing through 3 years of age. ${ }^{103-107}$ The possible relationship between HRV wheezing illness and genetic risk of childhood-onset asthma was studied in a group of prospectively studied children. ${ }^{108}$ The participants were children who had been studied since birth and cultured for HRV. In children who had HRV wheezing illnesses, there was significant association with 17q21 gene locus.

\section{COPD and HRV Infection}

Multiple longitudinal studies have documented the importance of respiratory viral infections in acute exacerbations of chronic obstructive pulmonary disease (COPD). ${ }^{109-113}$ Other studies, using PCR techniques for respiratory virus detection, have found that more than $40 \%$ of COPD exacerbations are associated with respiratory viruses, especially HRVs. Inflammatory mediators, especially IL-8, have been found in increased levels of respiratory secretions obtained from stable COPD patients.

Studies have demonstrated an increase in Staphylococcus aureus and Streptococcus pneumonia adherence to respiratory epithelial cells infected with HRV. In an in vitro study using primary differentiated human cell culture lines, a strain of nontypeable Haemophilus influenza was found to potentiate airway epithelial cell responses to HRV by increasing ICAM-1 and Toll-like receptor-3 expression. ${ }^{114}$ However, it is unclear whether the interaction of respiratory virus with bacterial pathogens is a common cause of exacerbations of COPD or whether respiratory viruses, such as HRV, cause these pulmonary complications.

\section{AOM and HRV Infections}

Viruses, especially HRVs, result in an inflammatory reaction that results in mucociliary damage, impaired middle ear function, and increased mucus in the Eustachian tube. This leads to superinfection of the middle ear by bacteria and fluid accumulation (effusion). Recent studies detected HRVs in $40 \%$ of children with otitis media with effusion. ${ }^{115-118}$ HRVs were cultured in $24 \%$ of nasopharyngeal specimens. In a prospective study of 121 otitis-prone children, nasopharyngeal swabs were assayed by PCR for respiratory viruses and by culture for bacterial pathogens. HRVs were found at baseline in $30 \%$ of specimens. Positive PCR tests for HRV correlated with culturing Moraxella catarrhalis and S. pneumonia but not nontypeable $H$. influenzae. HRV and bacterial pathogens were found in otitis-prone children even in the absence of clinical symptoms. Most new otitis media episodes are coincident with a HRV URL.

In a recently published study in South African children with AOM, $74.2 \%$ of cases had respiratory viruses detected from middle ear fluid specimens. ${ }^{119}$ HRVs were detected in $37.7 \%$ of children with AOM. Respiratory viruses were recovered in $72 \%$ of episodes which had negative bacterial cultures. HIV status did not alter the spectrum of respiratory viruses recovered.

\section{Rhinosinusitis and HRV Infections}

Patients with the common cold syndrome have sinus abnormalities detectable by computed tomography. ${ }^{120,121}$ Abnormalities are most frequently detected in the maxillary and ethmoid sinuses, and resolve without antibiotics in $80 \%$ of patients followed over several weeks. Less than $20 \%$ of cases of viral rhinosinusitis are complicated by bacterial infection. ${ }^{122}$ In a study of 20 adults with acute rhinosinusitis, $15 \%$ had virus cultures positive for HRV, but $50 \%$ were positive using RT-PCR on maxillary sinus aspirates or nasal swabs. ${ }^{123}$ Intranasal pressure increases following nose blowing, sneezing, and coughing, and is high enough to propel virus-infected nasal reactions into the sinuses. ${ }^{124}$

\section{Community-Acquired Pneumonia and Bronchiolitis in HRV Infections}

Multiple studies using PCR assays have shown that HRVs do cause community-acquired pneumonia (CAP) in both children and adults. ${ }^{125-128}$ Studies in children have reported a range of 0 to $52 \%$ positive specimens for HRV (-Table 2). ${ }^{129-148}$ Bronchiolitis in children has been commonly reported in infants and young children. The most commonly reported virus recovered in acute cases has been RSV. As with CAP series, mixed infections with a second respiratory virus were common. In studies testing for respiratory viruses in adults with CAP, HRV was detected in 4 to $40 \%$ of cases (- Table 3). ${ }^{149-155}$ As many cases of CAP had mixed infections, it is difficult to be certain if the HRV contributed to CAP.

\section{Cystic Fibrosis and HIV Infections}

A few studies have examined the role of respiratory viral infections in $\mathrm{CF}$ patients. ${ }^{156}$ Picornavirus was detected in more than $40 \%$ of URIs in children with underlying CF. ${ }^{157}$ There was no difference in pulmonary function in those children with proven HRV infection versus other respiratory viruses. Smyth et al followed up 108 patients with CF for 1 year, and detected HRV in $16 \%$ of exacerbations. ${ }^{158}$ Those patients with proven HRV infection did not show deterioration in clinical activity, but did receive more days of intravenous antibiotics. Goffard et al reported on 64 samples from 46 adult patients with $\mathrm{CF} .{ }^{159} \mathrm{HRV}$ s were most frequently identified in CF patients with clinical exacerbations and identified in $14 \%$. Ramirez et al found similar HRV detection in CF patients with exacerbations and measured increased 
Table 2 HRV isolates in childhood community-acquired pneumonia and/or bronchiolitis

\begin{tabular}{|c|c|c|c|c|c|}
\hline Reference & Country & Design & Clinical & Specimen & $\% \mathrm{HRV} \oplus$ \\
\hline Choi et al $^{129}$ & Korea & Retrospective & $\mathrm{Pn}$ & $\mathrm{BAL}$ & 23.8 \\
\hline Launes et al ${ }^{130}$ & Spain & Prospective & $\mathrm{Pn}$ & NPA & 52 \\
\hline García-García et al ${ }^{131}$ & Spain & Prospective & $\mathrm{Pn}$ & NPA & 19 \\
\hline Miller et al $^{132}$ & Argentina & Prospective & $\mathrm{Br}$ & NS & 40 \\
\hline Esposito et al $^{133}$ & Italy & Prospective & $\mathrm{Pn}$ & NS & 29 \\
\hline Homaira et al ${ }^{134}$ & Bangladesh & Prospective & $\mathrm{Pn}$ & NW & 12 \\
\hline Guerrier et al ${ }^{135}$ & Cambodia & Prospective & $\mathrm{Pn} / \mathrm{Br}$ & NPS & 34 \\
\hline Cho et $\mathrm{al}^{136}$ & Korea & Prospective & $\mathrm{Pn}$ & NS & 18.5 \\
\hline Suzuki et al ${ }^{137}$ & Philippines & Prospective & $\mathrm{Pn}$ & NPS & 30.5 \\
\hline Uršič et al ${ }^{138}$ & Slovenia & Prospective & $\mathrm{Pn} / \mathrm{Br}$ & NPS/TS & 33.1 \\
\hline Pretorius et al ${ }^{139}$ & South Africa & Prospective & SARI & NPS & 25 \\
\hline Lu et al $^{140}$ & China & Prospective & $\mathrm{Pn}$ & NPA & 30.9 \\
\hline Chidlow et al ${ }^{141}$ & New Guinea & Prospective & $\mathrm{Pn}$ & NS & 63 \\
\hline Ghani et al ${ }^{142}$ & South Africa & Retrospective & $\mathrm{Pn} / \mathrm{Br}$ & NPS/TS/BAL & 39 \\
\hline Chen et al $^{143}$ & Taiwan & Prospective & $\mathrm{Br}$ & NPS & 12.4 \\
\hline Antunes et al $^{144}$ & Portugal & Prospective & $\mathrm{Br}$ & $?$ & 0 \\
\hline Mansbach et al ${ }^{145}$ & United States & Prospective & $\mathrm{Br}$ & NPA & 25.6 \\
\hline Zeng et al ${ }^{146}$ & China & Prospective & $\mathrm{Pn} / \mathrm{Br}$ & NPA & 23.2 \\
\hline Ouédraogo et al ${ }^{147}$ & Burkina Faso & Prospective & $\mathrm{Pn} / \mathrm{Br}$ & NPA & 40 \\
\hline Gooskens et al ${ }^{148}$ & The Netherlands & Retrospective & LRTI & NPA/TS/S & 30 \\
\hline
\end{tabular}

Abbreviations: BAL, bronchoalveolar lavage; Br, bronchiolitis; HRV, human rhinovirus; NPA, nasopharyngeal aspirate; NS, nasal swab; NW, nasal wash; Pn, pneumonia; TS, throat swab.

chemokine expression in sputum samples of HRV-positive patients. $^{160}$

\section{HRV Infections in Immunocompromised Hosts}

Respiratory virus infections are common causes of acute respiratory illness in patients after solid-organ transplantation or following bone marrow transplantation. ${ }^{161-166}$ In these immunocompromised patients, HRV was the number one detected respiratory virus by PCR assays. Ison et al found an $83 \%$ (5/6) fatality rate in hematopoietic stem cell transplantation patients with bronchoalveolar lavage (BAL)-posi- tive samples for HRV.162 In a study of 215 patients with underlying HCT, 30\% had infections at 100 days posttransplant.166 The incidence for HRV was $22.3 \%$. Median duration of virus shedding was 3 weeks. HRV infection was associated with URI symptoms.

In a prospective study of patients with malignancies and neutropenia, a virus was detected in $35 \%$ of patients. ${ }^{167}$ HRVs were the most common virus detected by quantitative PCR in nasopharyngeal aspirates. In a prospective, multicenter study in children with cancer and fever and neutropenia, 57\% had a virus detected by PCR-DNA. A third of the patients had mixed

Table 3 HRV-associated CAP in adults

\begin{tabular}{|l|l|l|l|l|}
\hline Reference & Country & Design & Clinical & \% All virus + \% HRV \\
\hline Qu et al ${ }^{149}$ & China & Prospective & CAP & 15.2 \\
\hline Seo et al & Korea & Prospective & LRTI & 12.0 \\
\hline Walker and Ison ${ }^{151}$ & United States & Retrospective & CAP & 40 \\
\hline Drieghe et al ${ }^{152}$ & Belgium & Prospective & LRTI & 5.2 \\
\hline Fica et al & Chile & Prospective & CAP & 23.7 \\
\hline Zhan et al & China & Prospective & CAP & 4.0 \\
\hline Jain et al & Ch5 & Prospective & CAP & 30.0 \\
\hline
\end{tabular}

Abbreviations: CAP, community-acquired pneumonia; HRV, human rhinovirus; LRTI, lower respiratory tract infection. 
HRV/bacterial infections. ${ }^{168}$ HRVs were the second most detected virus; RSV was most frequently identified. Significant morbidity and mortality in posttransplant patients have been reported following HRV infections. ${ }^{169}$ In bone marrow transplant recipients with fever and URI symptoms, HRV was the most commonly detected respiratory virus. ${ }^{170}$

\section{Nosocomial HRV Infections}

Hospital outbreaks of HRV infections have been reported in neonatal intensive care units (ICUs) and long-term care facilities. ${ }^{171-179}$ In one study, neonates acquired HRV infection during their hospital stay. ${ }^{179}$ In long-term care facilities where HRV outbreaks have occurred, there were potential deaths associated with the infection. Guidelines for hospital isolation recommend droplet precautions for patients with known HRV infection. ${ }^{180}$

\section{Treatment}

There are no approved antiviral medications for HRV respiratory tract infections. Anticholinergic medications can be used for rhinorrhea. Nasal congestion can be alleviated by nasal and systemic decongestants. Several studies have suggested that heated, humidified steam may reduce nasal congestion in common colds, but the data are not conclusive. ${ }^{181}$ Cough is a common accompanying problem in respiratory viral infections and can be suppressed with nonprescription cough suppressants. Other symptoms such as sore throat, myalgia, fever, or headache can be controlled with nonsteroidal antiinflammatory drugs. Antibiotics are inappropriate for treating these viral infections.

Compounds targeting cell susceptibility, virus attachment, receptor blockage, virus uncoating, RNA replication, and viral protein synthesis have been evaluated. Although several agents have demonstrated both in vitro and in vivo success, none have received U.S. Food and Drug Administration approval due to poor bioavailability, poor side-effect profile, or limited potency. ${ }^{182}$ Viral capsid-binding compounds, such as pleconaril, block virus uncoating in vitro. ${ }^{183}$ Clinical trials demonstrated significant reduction in duration of respiratory symptoms in individuals receiving pleconaril, but the drug has not been approved.

Alternative medications, such as Echinacea angustifolia or zinc lozenges, have been tested in several volunteer trials but are not currently thought to be clinically effective. ${ }^{184-187}$ All of these studies suffer from inadequate control groups or incomplete virologic evaluation.

Quinolones have been used to treat exacerbation of COPD because of their broad antibacterial spectrum and anti-inflammatory properties. Recently, levofloxacin has been found to inhibit HRV infection in primary cell cultures employing human tracheal epithelial cells. ${ }^{188}$ Levofloxacin pretreatment decreased mRNA levels of ICAM-1. Macrolides have also been reported to reduce ICAM-1 expression and HRV-induced cytokines in vitro and in vivo. ${ }^{189}$

A recent randomized controlled study evaluated the clinical benefit of oral prednisolone for treating a first episode of HRV-associated wheezing in young children younger than 23 months. ${ }^{190}$ No long-term benefits were demonstrated in those children receiving oral prednisolone with their first HRV-associated wheezing episode. Short-term benefits were found in those receiving the oral prednisolone. This included less cough, rhinitis, and night-time respiratory symptoms. In a subset of children who had high viral loads ( $>7,000$ copies/ $\mathrm{mL}$ ), a long-term benefit of prednisolone therapy was detected. Future studies will have to confirm these findings before a general recommendation can be made for corticosteroid treatment in asthma-prone children with HRV-associated wheezing episodes.

\section{Prevention}

HRV can be recovered from the hands of approximately $40 \%$ of adults with colds. Hand-to-hand transmission of HRV has led to the evaluation of disinfectants that will eliminate virus on human skin. Trials to reduce hand transmission have reported differing results. ${ }^{191,192}$ A recently published study in Bangladesh demonstrated that nasal swab samples and paired hand rinse samples had HRV detected by rRT-PCR in 21 and $29 \%$ of samples, respectively. ${ }^{193}$

A study using $2 \%$ of aqueous iodine decreased transmission in family members who were exposed to HRV-infected individuals. An evaluation of virucidal hand treatments confirmed the prevention of HRV infections by organic acids but not ethanol. ${ }^{192}$ Hand washing with soap and water effectively cleans HRV-contaminated hands better than single treatment with ethanol hand rub. ${ }^{192}$

Vaccines have not been thought to be useful against HRVs because of the serotype-specific neutralizing antibodies produced following infection and because of the numerous serotypes. ${ }^{194-197}$ However, recent studies in a mouse model have reported development of cross-serotype reactive antibodies to VP1, suggesting a basis for successful antibodymediated vaccine development. Future studies will need to confirm and expand these preliminary observations.

\section{Coronaviruses}

\section{Virology}

Coronaviruses are positive, single-stranded RNA viruses that replicate in the cytoplasm and bud into cytoplasmic vesicles from the endoplasmic reticulum. Coronaviruses are divided into three groups: alpha, beta, and gamma. CD13 (human aminopeptidase $\mathrm{N}$ ) is the cellular receptor for $\mathrm{HCoV}-229 \mathrm{E}$ (-Table 4). ${ }^{198-200}$ Recent studies have shown that the newly reported HCoV-NL63 does not use CD13 as the receptor cell entry. HCoV-NL63, along with severe acute respiratory syndrome (SARS)-CoV, uses angiotensin-converting enzyme 2 (ACE2) as the entry receptor. ${ }^{201}$ ACE2 is found on the ciliated nasal and tracheobronchial epithelial cells. The receptor for $\mathrm{HCoV}-\mathrm{OC} 43$ is not known. Carcinoembryonic antigen (CEA) is the receptor for mouse hepatitis virus. ${ }^{202}$ Phylogenetic relationships between coronaviruses have been based on deduced amino acid sequences of the coronavirus replicase, ORF1b gene.

Middle East respiratory syndrome (MERS)-CoV belongs to the genus Betacoronavirus ( $\mathrm{BCoV}$ ) in the family Coronaviridae. ${ }^{17}$ It is the first lineage $C \beta C o V$ and the sixth coronavirus known to infect humans. MERS-CoV is an enveloped, 
Table 4 Coronavirus receptors

\begin{tabular}{|l|l|l|}
\hline Virus & Group & Receptor \\
\hline Human coronavirus 229E (HCoV-229E) & Alpha & APN \\
\hline Bat coronaviruses (BCoVs-multiple species) & Alpha & Unknown \\
\hline Human coronavirus NL63 (HCoV-NL63) & Alpha & ACE2 \\
\hline Severe acute respiratory syndrome coronavirus (SARS-CoV) & Beta & ACE2 \\
\hline Bat SARS-related coronavirus (Bat-SCoV) & Beta & ACE2? \\
\hline Middle East respiratory syndrome coronavirus (MERS-CoV) & Beta & DPP4 \\
\hline Human coronavirus OC43 (HCoV-OC43) & Beta & Unknown \\
\hline
\end{tabular}

Abbreviations: ACE2, angiotensin-converting enzyme 2; APN, aminopeptidase N; DPP4, dipeptidyl peptidase 4.

positive-sense, single-stranded RNA virus. The replication cycle is similar to other CoVs. The host cell receptor for the MERS-CoV S protein is dipeptidyl peptidase-4 (DPP4) or CD26. This receptor is expressed on endothelial and epithelial cells of the kidney, lung, small intestine, liver, as well as on immune cells. This ability to infect many different organ cells may explain the extrapulmonary clinical characteristics in patients. After uncoating, there is translation of $\mathrm{ORF} / \mathrm{a} / \mathrm{b}$, followed by transcription and genome replication. Following translation on the rough ER, budding and assembly of virions occur in the cytoplasm with exocytosis and virion release. ACE2 is a SARS-CoV receptor. Upon SARS-CoV infection, ACE2 expression in lungs is markedly downregulated and therefore helps explain SARS pathogenesis and progression to acute respiratory distress syndrome (-Table 5 ).

\section{Pathogenesis}

Coronaviruses attach to cellular receptors by the spike proteins on their surface. ${ }^{203,204}$ Internalization into host cells occurs by direct fusion with the plasma membrane or by endocytosis. Posttranslational proteolytic processes are important regulatory mechanisms. Polyproteins are cleaved by viral proteases, facilitating assembly of subunit protein complexes that are responsible for replication and transcription. ${ }^{205}$ There is little information on the host response to coronavirus replication. Humoral immune responses are detectable following natural infection, but the role of cellmediated immunity is largely unknown. ${ }^{206,207}$

There are several in vitro and in vivo differences between SARS-CoV and MERS-CoV infections. There are radiographic differences, as well as differences in cytopathic effect. The

Table 5 SARS and MERS coronavirus infections: virology, epidemiology, and diagnostic tests

\begin{tabular}{|l|l|l|}
\hline \multicolumn{2}{|l|}{ SARS } & MERS \\
\hline Virology & SARS-CoV & MERS-CoV \\
\hline Virus & BßCoV & CBCoV \\
\hline Phylogeny & ACE2 & DPP4 (CD26) \\
\hline Host receptor & Endosomal fusion & Cell membrane fusion \\
\hline Cell entry pathway & \multicolumn{2}{|l|}{} \\
\hline Epidemiology & China & Middle East \\
\hline Origin & Bats & Bats \\
\hline Natural reservoir & Civets, raccoon dogs & Camels \\
\hline Intermediate host & Winter & $?$ \\
\hline Seasonality & Person to person, droplet, contact, airborne & Animal to human, droplet, contact, airborne (?) \\
\hline Mode of transmission & 2-14 d (up to 21 d) & 2-15 d \\
\hline Incubation period & \multicolumn{2}{|l}{} \\
\hline Diagnosis & Lower respiratory tract & Lower respiratory tract \\
\hline $1^{\circ}$ Specimens & + & + \\
\hline RT-PCR test &
\end{tabular}

Abbreviations: CoV, coronavirus; MERS, Middle East respiratory syndrome; RT-PCR, reverse transcription-polymerase chain reaction; SARS, severe acute respiratory syndrome. 
Table 6 Clinical findings, treatment, and prevention of SARS and MERS coronavirus infections

\begin{tabular}{|c|c|c|}
\hline & SARS & MERS \\
\hline \multicolumn{3}{|l|}{ Clinical findings } \\
\hline Presenting syndrome & CAP or HAP & CAP or HAP \\
\hline Extrapulmonary manifestations & Diarrhea & Acute renal failure, diarrhea \\
\hline X-ray findings & Ground-glass opacities, ARDS & Focal to diffuse and/or consolidation, ARDS \\
\hline Case-fatality rate & $\sim 10$ & $>35$ \\
\hline \multicolumn{3}{|l|}{ Treatment and prevention } \\
\hline Antivirals used & Interferon and ribavirin & Ribavirin and IFN- $\alpha 2 b$ \\
\hline Passive immunization & Convalescent plasma therapy & Adaptive transfer of serum \\
\hline Vaccine development & Yes-early phases & Yes-early phases \\
\hline
\end{tabular}

Abbreviations: ARDS, acute respiratory distress syndrome; CAP, community-acquired pneumonia; HAP, healthcare assisted pneumonia; IFN, interferon; MERS, Middle East respiratory syndrome; SARS, severe acute respiratory syndrome.

host response to infection appears to be different. For example, there are observed differences in sensitivity to type I IFN in vitro. MERS-CoV is more sensitive to type I IFN compared with SARS-CoV. ${ }^{208}$ SARS pathogenesis is controlled in part by innate immune signaling. SARS-CoV encodes proteins that modulate innate immune signaling by antagonism of IFN induction and by avoiding IFN-stimulated gene effector functions (-Table 6). ${ }^{209}$

\section{Epidemiology}

Coronaviruses were detected as agents of respiratory infections approximately 40 years ago. ${ }^{210-212}$ They were later identified as coronaviruses, labeled "OC43" and "229E," and accepted as a new genus in 1975. In epidemiologic studies in adults, coronaviruses were estimated to cause $15 \%$ of adult common colds. Coronaviruses were found to cause epidemics every 2 to 3 years with reinfections being common. All ages are susceptible. From epidemiologic studies, coronaviruses were found to be associated with respiratory illnesses, usually in the upper respiratory tract, but occasionally causing pneumonia. In temperate climates, $\mathrm{HCoV}-\mathrm{OC} 43$ and $\mathrm{HCoV}-229 \mathrm{E}$ are transmitted primarily during the winter. They have been linked to asthma and COPD exacerbations in children and adults. ${ }^{125,213}$

In 2004 and 2005, three closely related coronavirus species were reported. ${ }^{214-219}$ NL63 was isolated from a 7-month-old girl with coryza, conjunctivitis, fever, and bronchiolitis. From epidemiologic studies, patients with $\mathrm{HCoV}-\mathrm{NL63}$ have ranged in age from 1 month to 100 years, with the highest infection rate occurring before age 5 years. Using molecular probes that targeted conserved regions of the coronavirus genome, a related coronavirus ( $\mathrm{HCoV}-\mathrm{NH}$ ) was found in 79 of 895 young children tested by RT-PCR on respiratory specimens.

In a prospective study in Hong Kong, coronaviruses were detected in $2.1 \%$ of patients admitted to the hospital with signs and symptoms of acute respiratory illness. ${ }^{220}$ Of the 87 infected patients, 13 were positive for HCoV-HKU1, 17 were positive for $\mathrm{HCoV}-\mathrm{NL} 63,53$ were positive for $\mathrm{HCoV}-\mathrm{OC} 43$, and 4 were positive for 229E. HCoV-HKU1 and $\mathrm{HCoV}-\mathrm{OC} 43$ peak in the winter months. Upper respiratory tract illness was the most common presentation for HCoV-HKU1 infections. $\mathrm{HCoV}-\mathrm{NL63}$ infections occurred in early summer and fall but not in the winter.

Using newer molecular assays, the group at Vanderbilt reassessed the role of the newly described coronaviruses in a large cohort of healthy children who had been followed up prospectively for 20 years. ${ }^{221}$ Of the LRI samples available for screening, $8.4 \%$ had positive results for $\mathrm{HCo}-\mathrm{V}$ and all were younger than 2 years. AOM was found in half of the HCo-Vinfected children, but none of the children were hospitalized. Of the URI samples tested, $4.7 \%$ had detectable HCo-V RNA. Fifty-one percent of these positive children were diagnosed with AOM. The burden of URI attributable to $\mathrm{HCo}-\mathrm{V}$ had significant year-to-year variation.

A recent study has provided evidence of genetic variability in OC43 strains. ${ }^{222}$ The complete nucleotide sequence of two contemporary OC43 strains compared with the prototype strain (ATCC VR 759) demonstrated important amino acid substitutions in the potential cleavage site sequence of the spike protein.

In 2002, the first cases of SARS were reported in Guangdong Province of China. ${ }^{223}$ Over the next few months, 29 countries reported cases in more than 8,000 patients with approximately $10 \%$ fatalities. A patient who acquired SARS in Guangdong traveled to Hong Kong and is thought to be the index case for over half of the cases. It was different from known human and animal coronaviruses by DNA sequencing. This new coronavirus was cultured from Himalayan palm civets, but it is now thought that bats are the primary reservoir (-Fig. 1). SARS infected more than 8,000 people resulting in more than 700 deaths.

MERS epidemiology originally implicated the dromedary camel as the source of human cases (- Fig. 1). . 24,225 Of the first 500 confirmed cases, $62 \%$ required hospitalization. Comorbid medical conditions were common and males were more likely to be identified as infected. The median age was 56 years. Secondary cases were commonly identified in younger health care workers. The incubation period was 5.2 days (range: $1.9-14.7$ days). Mortality rates were reported to be approximately $35 \% .226,227$ 


\section{A. Genome Structure}

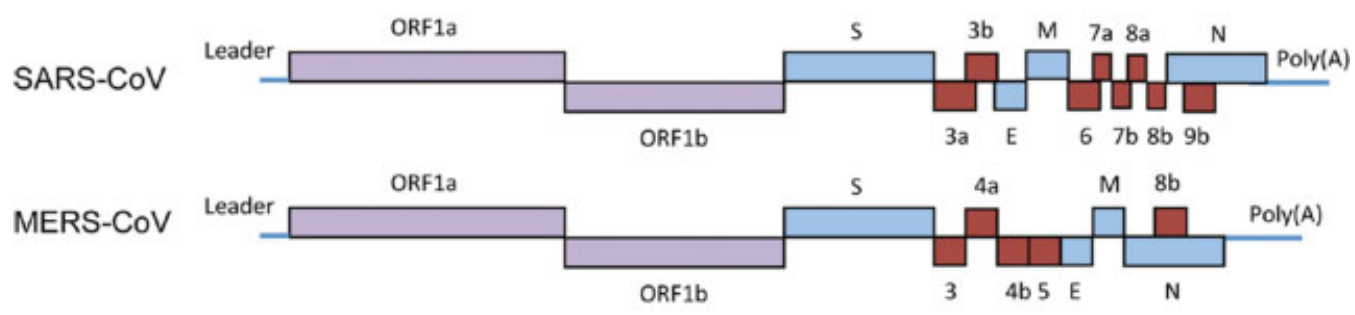

B. Transmission
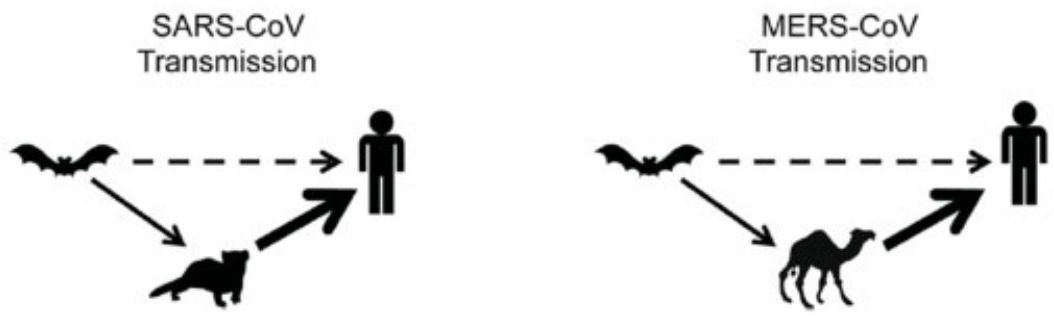

Fig. 1 (A) Genome structures of SARS-CoV and MERS-CoV. The single-stranded, positive-sense coronavirus genomes encode the structural proteins (blue), membrane (M), spike (S), envelope (E), and nucleocapsid (N), two replicase polyproteins (purple), ORF1a and ORF1b, and unique accessory proteins (red) that perform important functions in coronavirus replication and pathogenesis, such as blocking the innate immune signaling pathway. (B) Transmission routes. SARS-CoV transmission is thought to be from bats harboring SARS-like viruses to palm civet cats, which infected humans. SARS-CoV could also have been transmitted from bats to humans directly. MERS-CoV is thought to be transmitted from camels to humans, with the possibility that at some point bats infected camels. The dashed line identifies a low-level transmission event, the thin solid line identified a potential transmission event, and the thick solid line identifies a probable transmission event. CoV, coronavirus; MERS, Middle East respiratory syndrome; SARS, severe acute respiratory syndrome. (Reproduced from Coleman CM, Frieman MB. Coronaviruses: important emerging human pathogens. J Virol 2014;88:5209. doi: 10.1128/JVI.03488-13 with permission of the American Society for Microbiology.)

In May 2014, two cases of MERS-CoV infection in the United States were reported by the Centers for Disease Control and Prevention (CDC). ${ }^{228,229}$ Both patients had acquired their infection while working in health care in Saudi Arabia. No contacts of these patients developed infections with MERS-CoV.

\section{Diagnosis}

Coronaviruses require special cell lines or organ culture for detection by cultivation methods. ${ }^{230}$ These cell or organ culture techniques are labor intensive, time consuming, and relatively insensitive. Coronaviruses have also been detected by RT-PCR with greater sensitivity than standard culture techniques. $^{231}$

SARS-CoV was initially detected by RT-PCR and culture. Viral RNA is found in high levels in the feces of SARS patients. To confirm SARS-CoV infection, the WHO criteria require detection of viral RNA by PCR, increase in antibody titers in body fluids, or isolation of SARS-CoV from clinical isolates. ${ }^{232}$ Laboratory diagnostic methods for SARS-CoV include (1) viral RNA detection using RT-PCR, (2) immunofluoroscent antibody (IFA), and (3) ELISA. Virus isolation is less sensitive than these other methods and requires a biosafety level 3 (BSL-3) facility.

Antibody assays are reported for coronaviruses, but are not readily available or helpful clinically. Complement-fixing and ELISA antibody assays for coronaviruses 229E and OC43 have been published, but are not available in clinical laboratories. $^{233,234}$ Therefore, serologic tests for antibody-specific responses are mainly reserved for research or epidemiologic studies.

Serological assays are a complement to nucleic acid detection assays for SARS-CoV and MERS-CoV. ${ }^{235-237}$ They have been helpful in identifying the source of the infection, in transmission pattern analysis, patient contact studies, and diagnosing asymptomatic cases. Even with the number of assays available after the SARS and MERS outbreak, differentiating HCoVs by serologic means remains a problem. Viral neutralization tests remain the most specific assay available, but are limited to only a few laboratories.

Animal virologic data from surveillance studies support the theory that MERS originated from bats in Africa and crossed species barriers to infect camels many years ago. Infected camels were then transported to the Middle East where they transmitted MERS-CoV to humans. A recent report showed through complete genome sequencing that a virus isolated from a dromedary camel was identical to a human strain isolated from sick humans who had developed MERS following close contact with sick camels. ${ }^{238}$ The mode of transmission from camels to humans is currently unknown, although droplet transmission seems likely.

Laboratory confirmation of MERS required nucleic acid amplification assays. The WHO criteria for confirmed cases includes (1) + RT-PCR for two different specific targets or (2) + RT-PCR from one specific target plus an additional different RT-PCR product sequenced and confirmed as MERS-CoV. A BSL3 is required for viral culture and neutralizing antibody detection assays. 


\section{Clinical Features}

In a prospective study of respiratory viral infections among hospitalized patients, 5.7\% had coronaviruses identified. ${ }^{220}$ The 47 coronavirus infections represent $10.5 \%$ of all the respiratory viral infections. In 14 patients, coronaviruses were associated with another respiratory virus. Lower respiratory tract infections (bronchitis, bronchiolitis, and pneumonia) were far more common than upper respiratory tract (rhinitis, pharyngitis, and laryngitis) infections, 75 versus $25 \%$, respectively. Over half of the infections were due to OC43-like strains. Approximately $20 \%$ were due to $229 \mathrm{E}-$ like strains and approximately 20\% were due to NL63-strains. Coronavirus infections in the first year of life were associated predominantly with OC43-like strains.

HCoV was identified in $5.4 \%$ of specimens from 279 hospitalized adult patients with lower respiratory tract infections. ${ }^{239,240}$ The most frequently identified isolates were HCoV-OC43 in 12, followed by HCoV-229E in 7, HCoV-NL63 in 6 , and HCoV-HKU1 in 4 specimens. Many patients had highrisk underlying conditions. In several recent studies evaluating multiplex PCR assays, HCoVs were detected in 3 to $8 \%$ of hospitalized children younger than 5 years with acute respiratory illnesses. ${ }^{241-243}$

Patients with SARS present with fever, cough, and/or myalgias. Dyspnea and hypoxemia were noted during the second week of illness. Rapidly progressive respiratory failure then occurred in a subset of patients. Patients appeared to be contagious after lower respiratory tract signs were observed. ${ }^{244,245}$

Nonspecific presenting symptoms are common in MERSCoV-infected patients. Fever, chills, and sore throat are frequently reported. ${ }^{246}$ Respiratory tract symptoms are also quite common. Within a few days of symptoms, respiratory failure can develop. Chest radiographic findings progress from a unilateral focal lesion to extensive multifocal or bilateral involvement, but are not specific to MERS-CoV infections. ${ }^{247,248}$ The most common CT findings are bilateral, often basilar, airspace involvement. Cavitation has not been reported. Late CT findings in recovered patients may include fibrotic changes and organizing pneumonia.

Acute renal failure has often been observed during the second week of illness with MERS virus. This was also seen in a small percentage of SARS patients. Dialysis was often required. Other nonrespiratory tract involvement has been reported to include diarrhea (7-25\% of patients), nausea, vomiting, pericarditis, and arrhythmias. ${ }^{249}$

Complications of MERS include superinfection or coinfection, septic shock, and delirium. ICU care is often needed within 5 days of admission. The case-fatality rates have ranged from 25 to $76 \%$. As more cases were identified, there have been more asymptomatic or mild cases identified. These have predominantly been in young, healthy women without significant comorbidities.

\section{Treatment}

There are no published randomized controlled trials of specific antiviral agents in the treatment of SARS or MERS. Supportive therapy is currently the only recommended plan.
When renal failure occurs, renal dialysis is necessary. Mechanical ventilation in an ICU is often required. Several candidate antiviral agents have been identified and include IFNs, ribavirin, and cyclophilin inhibitors. ${ }^{250-257}$ Both in vitro cell culture experiments and animal studies have shown antiviral activity of these agents against MERS-CoV. However, very few human cases who received a combination of IFN- $\alpha 2 b$, ribavirin, and corticosteroids survived.

\section{Infection Control}

Prompt isolation of suspected SARS or MERS cases and contact tracing of case contacts are the keys to preventing nosocomial transmission..$^{258-260}$ Standard, contact, and droplet precautions should be used in all cases. Airborne precautions should be employed for aerosol-generating procedures, bronchoscopy, tracheostomy, and airway insertion.

Vaccine design for SARS-CoV and MERS-CoV has focused on the development of chimeric spike glycoproteins containing neutralizing epitopes from multiple strains within or across subgroups. ${ }^{261-267}$ Inclusion of nucleocapsid protein in chimeric vaccines could broaden the protective response. The $S$ protein is the major determinant of protective immunity. Antibodies against $S$ protein appeared to protect from SARS-CoV challenges in animal studies. $\mathrm{N}$ protein-specific immune response provides little protection and only crossreact within, but not between, subgroups. Thus, there are no approved vaccines for MERS or any of the CoVs. The use of convalescent-phase plasma or immune globulin with high titers of neutralizing antibody has not been evaluated in randomized controlled trials. ${ }^{268}$

\section{Conclusion}

HRVs and HCoVs cause significant morbidity in immunocompetent people and in patients with underlying chronic or immunosuppressed medical conditions. Newer diagnostic tests have expanded our understanding of these respiratory viruses in clinical infections. These sensitive diagnostic tests have been used to detect new HRVs, such as HRV-C. Recent studies on the pathogenesis of HRVs and the host response to this group of viruses have provided insights into potential targets for therapeutic interventions. The recent outbreaks of SARS and MERS pose special problems in treatment and infection control. ${ }^{269-271}$ Vaccine development for HCoVs and/or coronaviruses appears to be many years away.

\section{References}

1 Greenberg SB. Update on rhinovirus and coronavirus infections. Semin Respir Crit Care Med 2011;32(4):433-446

2 Greenberg SB. Human rhinovirus infections. In: Singh S, ed. Human Respiratory Viral Infections. Boca Raton: CRC Press; 2014: 353-376

3 Cecere TE, Todd SM, Richmond OB. Human coronavirus respiratory infections. In: Singh S, ed. Human Respiratory Viral Infections. Boca Raton: CRC Press; 2014:547-558

4 Jacobs SE, Lamson DM, St George K, Walsh TJ. Human rhinoviruses. Clin Microbiol Rev 2013;26(1):135-162 
5 Kennedy JL, Turner RB, Braciale T, Heymann PW, Borish L. Pathogenesis of rhinovirus infection. Curr Opin Virol 2012; 2(3):287-293

6 Greenberg SB, Allen M, Wilson J, Atmar RL. Respiratory viral infections in adults with and without chronic obstructive pulmonary disease. Am J Respir Crit Care Med 2000;162(1):167-173

7 El-Sahly HM, Atmar RL, Glezen WP, Greenberg SB. Spectrum of clinical illness in hospitalized patients with "common cold" virus infections. Clin Infect Dis 2000;31(1):96-100

8 Wedzicha JA. Role of viruses in exacerbations of chronic obstructive pulmonary disease. Proc Am Thorac Soc 2004;1(2):115-120

9 Johnston SL, Pattemore PK, Sanderson G, et al. Community study of role of viral infections in exacerbations of asthma in 9-11 year old children. BMJ 1995;310(6989):1225-1229

10 Hiatt PW, Grace SC, Kozinetz CA, et al. Effects of viral lower respiratory tract infection on lung function in infants with cystic fibrosis. Pediatrics 1999;103(3):619-626

11 Chonmaitree T, Howie VM, Truant AL. Presence of respiratory viruses in middle ear fluids and nasal wash specimens from children with acute otitis media. Pediatrics 1986;77(5):698-702

12 Pitkäranta A, Virolainen A, Jero J, Arruda E, Hayden FG. Detection of rhinovirus, respiratory syncytial virus, and coronavirus infections in acute otitis media by reverse transcriptase polymerase chain reaction. Pediatrics 1998;102(2, Pt 1):291-295

13 Wolfromm A, Porcher R, Legoff J, et al. Viral respiratory infections diagnosed by multiplex PCR after allogeneic hematopoietic stem cell transplantation: long-term incidence and outcome. Biol Blood Marrow Transplant 2014;20(8):1238-1241

14 Brebion A, Mirand A, Regagnon C, et al. Evaluation of real-time RT-PCR Rhino\&EV/Cc r-gene( $\left({ }^{\circledR}\right)$ (bioMérieux) kit versions 1 and 2 for rhinovirus detection. J Clin Virol 2015;62:110-113

15 Grijalva CG, Griffin MR, Edwards KM, et al. Concordance between RT-PCR-based detection of respiratory viruses from nasal swabs collected for viral testing and nasopharyngeal swabs collected for bacterial testing. J Clin Virol 2014;60(3):309-312

16 To KF, Lo AWI. SARS-CoV infections in humans. In: Singh S, ed. Human Respiratory Viral Infections. Boca Raton: CRC Press; 2014: 559-581

17 Chan JF, Lau SK, To KK, Cheng VC, Woo PC, Yuen KY. Middle East respiratory syndrome coronavirus: another zoonotic betacoronavirus causing SARS-like disease. Clin Microbiol Rev 2015; 28(2):465-522

18 Lee WM, Kiesner C, Pappas T, et al. A diverse group of previously unrecognized human rhinoviruses are common causes of respiratory illnesses in infants. PLoS ONE 2007;2(10):e966

19 Kuroda M, Niwa S, Sekizuka T, et al. Molecular evolution of the VP1, VP2, and VP3 genes in human rhinovirus species C. Sci Rep 2015;5:8185

20 Palmenberg AC, Spiro D, Kuzmickas R, et al. Sequencing and analyses of all known human rhinovirus genomes reveal structure and evolution. Science 2009;324(5923):55-59

21 Tapparel C, Junier T, Gerlach D, et al. New respiratory enterovirus and recombinant rhinoviruses among circulating picornaviruses. Emerg Infect Dis 2009;15(5):719-726

22 Blomqvist S, Savolainen C, Råman L, Roivainen M, Hovi T. Human rhinovirus 87 and enterovirus 68 represent a unique serotype with rhinovirus and enterovirus features. J Clin Microbiol 2002; 40(11):4218-4223

23 Hasegawa S, Hirano R, Okamoto-Nakagawa R, Ichiyama T, Shirabe K. Enterovirus 68 infection in children with asthma attacks: virus-induced asthma in Japanese children. Allergy 2011; 66(12):1618-1620

24 Jacques J, Moret $\mathrm{H}$, Minette D, et al. Epidemiological, molecular, and clinical features of enterovirus respiratory infections in French children between 1999 and 2005. J Clin Microbiol 2008; 46(1):206-213

25 Piralla A, Lilleri D, Sarasini A, et al. Human rhinovirus and human respiratory enterovirus (EV68 and EV104) infections in hospital- ized patients in Italy, 2008-2009. Diagn Microbiol Infect Dis 2012; 73(2):162-167

26 Rahamat-Langendoen J, Riezebos-Brilman A, Borger R, et al. Upsurge of human enterovirus 68 infections in patients with severe respiratory tract infections. J Clin Virol 2011;52(2): 103-106

27 Kim JH, Kwon HJ, Jang YJ. Effects of rhinovirus infection on the expression and function of cystic fibrosis transmembrane conductance regulator and epithelial sodium channel in human nasal mucosa. Ann Allergy Asthma Immunol 2012;108(3): 182-187

28 Jayaraman A, Jackson DJ, Message SD, et al. IL-15 complexes induce NK- and T-cell responses independent of type I IFN signaling during rhinovirus infection. Mucosal Immunol 2014; 7(5):1151-1164

29 Zaheer RS, Wiehler S, Hudy MH, et al. Human rhinovirus-induced ISG15 selectively modulates epithelial antiviral immunity. Mucosal Immunol 2014;7(5):1127-1138

30 Cakebread JA, Haitchi HM, Xu Y, Holgate ST, Roberts G, Davies DE. Rhinovirus- 16 induced release of IP-10 and IL- 8 is augmented by Th2 cytokines in a pediatric bronchial epithelial cell model. PLoS ONE 2014;9(4):e94010

31 Nakagome K, Bochkov YA, Ashraf S, et al. Effects of rhinovirus species on viral replication and cytokine production. J Allergy Clin Immunol 2014;134(2):332-341

32 Gulraiz F, Bellinghausen C, Dentener MA, et al. Efficacy of IFN- $\lambda 1$ to protect human airway epithelial cells against human rhinovirus 1B infection. PLoS ONE 2014;9(4):e95134

33 Miller EK, Hernandez JZ, Wimmenauer V, et al. A mechanistic role for type III IFN- $\lambda 1$ in asthma exacerbations mediated by human rhinoviruses. Am J Respir Crit Care Med 2012;185(5): 508-516

34 Cakebread JA, Xu Y, Grainge C, et al. Exogenous IFN- $\beta$ has antiviral and anti-inflammatory properties in primary bronchial epithelial cells from asthmatic subjects exposed to rhinovirus. J Allergy Clin Immunol 2011;127(5):1148-1154.e9

35 Hong JY, Bentley JK, Chung Y, et al. Neonatal rhinovirus induces mucous metaplasia and airways hyperresponsiveness through IL25 and type 2 innate lymphoid cells. J Allergy Clin Immunol 2014; 134(2):429-439

36 Arruda E, Pitkäranta A, Witek TJ Jr, Doyle CA, Hayden FG. Frequency and natural history of rhinovirus infections in adults during autumn. J Clin Microbiol 1997;35(11):2864-2868

37 Mäkelä MJ, Puhakka T, Ruuskanen O, et al. Viruses and bacteria in the etiology of the common cold. J Clin Microbiol 1998;36(2): 539-542

38 McErlean P, Shackelton LA, Andrews E, et al. Distinguishing molecular features and clinical characteristics of a putative new rhinovirus species, human rhinovirus C (HRV C). PLoS ONE 2008;3(4):e1847

39 Miller EK, Khuri-Bulos N, Williams JV, et al. Human rhinovirus C associated with wheezing in hospitalised children in the Middle East. J Clin Virol 2009;46(1):85-89

40 Renwick N, Schweiger B, Kapoor V, et al. A recently identified rhinovirus genotype is associated with severe respiratory-tract infection in children in Germany. J Infect Dis 2007;196(12): $1754-1760$

41 Savolainen-Kopra C, Blomqvist S, Kilpi T, Roivainen M, Hovi T. Novel species of human rhinoviruses in acute otitis media. Pediatr Infect Dis J 2009;28(1):59-61

42 Urquhart GE, Grist NR. Virological studies of sudden, unexplained infant deaths in Glasgow 1967-70. J Clin Pathol 1972;25(5): 443-446

43 Canducci F, Debiaggi M, Ceresola ER, et al. Infection and coinfection of human rhinovirus $C$ in stem cell transplant recipients. Clin Dev Immunol 2013;2013:236081

44 Khetsuriani N, Lu X, Teague WG, Kazerouni N, Anderson LJ, Erdman DD. Novel human rhinoviruses and exacerbation 
of asthma in children. Emerg Infect Dis 2008;14(11): 1793-1796

45 Kneider M, Bergström T, Gustafsson C, et al. Sequence analysis of human rhinovirus aspirated from the nasopharynx of patients with relapsing-remitting MS. Mult Scler 2009;15(4):437-442

46 Miller EK, Edwards KM, Weinberg GA, et al; New Vaccine Surveillance Network. A novel group of rhinoviruses is associated with asthma hospitalizations. J Allergy Clin Immunol 2009; 123(1):98-104.e1

47 Alper CM, Winther B, Mandel EM, Hendley JO, Doyle WJ. Rate of concurrent otitis media in upper respiratory tract infections with specific viruses. Arch Otolaryngol Head Neck Surg 2009;135(1): $17-21$

48 Xatzipsalti M, Kyrana S, Tsolia M, et al. Rhinovirus viremia in children with respiratory infections. Am J Respir Crit Care Med 2005;172(8):1037-1040

49 Tapparel C, L'Huillier AG, Rougemont AL, Beghetti M, Barazzone-Argiroffo C, Kaiser L. Pneumonia and pericarditis in a child with HRV-C infection: a case report. J Clin Virol 2009; 45(2):157-160

50 Jartti T, Lehtinen P, Vuorinen T, Koskenvuo M, Ruuskanen $\mathrm{O}$. Persistence of rhinovirus and enterovirus RNA after acute respiratory illness in children. J Med Virol 2004;72(4):695-699

51 Winther B, Hayden FG, Hendley JO. Picornavirus infections in children diagnosed by RT-PCR during longitudinal surveillance with weekly sampling: Association with symptomatic illness and effect of season. J Med Virol 2006;78(5):644-650

52 Dick EC, Blumer CR, Evans AS. Epidemiology of infections with rhinovirus types 43 and 55 in a group of university of Wisconsin student families. Am J Epidemiol 1967;86(2):386-400

53 Piralla A, Rovida F, Campanini G, et al. Clinical severity and molecular typing of human rhinovirus $C$ strains during a fall outbreak affecting hospitalized patients. J Clin Virol 2009;45(4): 311-317

54 Savolainen C, Mulders MN, Hovi T. Phylogenetic analysis of rhinovirus isolates collected during successive epidemic seasons. Virus Res 2002;85(1):41-46

55 Linder JE, Kraft DC, Mohamed Y, et al. Human rhinovirus C: Age, season, and lower respiratory illness over the past 3 decades. J Allergy Clin Immunol 2013;131(1):69-77.e1, 6

56 Mackay IM, Lambert SB, Faux CE, et al. Community-wide, contemporaneous circulation of a broad spectrum of human rhinoviruses in healthy Australian preschool-aged children during a 12-month period. J Infect Dis 2013;207(9):1433-1441

57 Meerhoff TJ, Houben ML, Coenjaerts FE, et al. Detection of multiple respiratory pathogens during primary respiratory infection: nasal swab versus nasopharyngeal aspirate using realtime polymerase chain reaction. Eur J Clin Microbiol Infect Dis 2010;29(4):365-371

58 Babady NE, Mead P, Stiles J, et al. Comparison of the Luminex xTAG RVP Fast assay and the Idaho Technology FilmArray RP assay for detection of respiratory viruses in pediatric patients at a cancer hospital. J Clin Microbiol 2012;50(7):2282-2288

59 Hammond SP, Gagne LS, Stock SR, et al. Respiratory virus detection in immunocompromised patients with FilmArray respiratory panel compared to conventional methods. J Clin Microbiol 2012;50(10):3216-3221

60 Rand KH, Rampersaud H, Houck HJ. Comparison of two multiplex methods for detection of respiratory viruses: FilmArray RP and xTAG RVP. J Clin Microbiol 2011;49(7):2449-2453

61 Loeffelholz MJ, Pong DL, Pyles RB, et al. Comparison of the FilmArray Respiratory Panel and Prodesse real-time PCR assays for detection of respiratory pathogens. J Clin Microbiol 2011; 49(12):4083-4088

62 Gwaltney JM Jr, Hendley JO, Patrie JT. Symptom severity patterns in experimental common colds and their usefulness in timing onset of illness in natural colds. Clin Infect Dis 2003;36(6):714-723
63 Harris JM II, Gwaltney JM Jr. Incubation periods of experimental rhinovirus infection and illness. Clin Infect Dis 1996;23(6): 1287-1290

64 Drews AL, Atmar RL, Glezen WP, Baxter BD, Piedra PA, Greenberg SB. Dual respiratory virus infections. Clin Infect Dis 1997;25(6): 1421-1429

65 Rehder KJ, Wilson EA, Zimmerman KO, Cunningham CK, Turner DA. Detection of multiple respiratory viruses associated with mortality and severity of illness in children. Pediatr Crit Care Med 2015;16(7):e201-e206

66 Damasio GA, Pereira LA, Moreira SD, Duarte dos Santos CN, DallaCosta LM, Raboni SM. Does virus-bacteria coinfection increase the clinical severity of acute respiratory infection? J Med Virol 2015;87(9):1456-1461

67 Wong-Chew RM, Espinoza MA, Taboada B, et al. Prevalence of respiratory virus in symptomatic children in private physician office settings in five communities of the state of Veracruz, Mexico. BMC Res Notes 2015;8:261

68 Wei L, Liu W, Zhang XA, et al. Detection of viral and bacterial pathogens in hospitalized children with acute respiratory illnesses, Chongqing, 2009-2013. Medicine (Baltimore) 2015; 94(16):e742

69 Morikawa S, Hiroi S, Kase T. Detection of respiratory viruses in gargle specimens of healthy children. J Clin Virol 2015;64:59-63

70 Gilca R, Amini R, Douville-Fradet M, et al. Other respiratory viruses are important contributors to adult respiratory hospitalizations and mortality even during peak weeks of the influenza season. Open Forum Infect Dis 2014;1(2):ofu086

71 Asner SA, Rose W, Petrich A, Richardson S, Tran DJ. Is virus coinfection a predictor of severity in children with viral respiratory infections? Clin Microbiol Infect 2015;21(3):264. e1-264.e6

72 Hombrouck A, Sabbe M, Van Casteren V, et al. Viral aetiology of influenza-like illness in Belgium during the influenza $A(\mathrm{H} 1 \mathrm{~N} 1)$ 2009 pandemic. Eur J Clin Microbiol Infect Dis 2012;31(6): 999-1007

73 Schnepf N, Resche-Rigon M, Chaillon A, et al. High burden of noninfluenza viruses in influenza-like illness in the early weeks of H1N1v epidemic in France. PLoS ONE 2011;6(8):e23514

74 Memish ZA, Assiri AM, Alshehri M, Hussain R, Alomar I. The prevalance of respiratory viruses among healthcare workers serving pilgrims in Makkah during the 2009 influenza A (H1N1) pandemic. Travel Med Infect Dis 2012;10(1):18-24

75 Pascalis H, Temmam S, Turpin M, et al. Intense co-circulation of non-influenza respiratory viruses during the first wave of pandemic influenza pH1N1/2009: a cohort study in Reunion Island. PLOS ONE 2012;7(9):e44755

76 Chang ML, Jordan-Villegas A, Evans A, et al. Respiratory viruses identified in an urban children's hospital emergency department during the 2009 influenza A(H1N1) pandemic. Pediatr Emerg Care 2012;28(10):990-997

77 Thiberville SD, Ninove L, Vu Hai V, et al. The viral etiology of an influenza-like illness during the 2009 pandemic. J Med Virol 2012;84(7):1071-1079

78 Yang Y, Wang Z, Ren L, et al. Influenza A/H1N1 2009 pandemic and respiratory virus infections, Beijing, 2009-2010. PLoS ONE 2012;7(9):e45807

79 Nisii C, Meschi S, Selleri M, et al. Frequency of detection of upper respiratory tract viruses in patients tested for pandemic H1N1/09 viral infection. J Clin Microbiol 2010;48(9):3383-3385

80 Kraft CS, Jacob JT, Sears MH, Burd EM, Caliendo AM, Lyon GM. Severity of human rhinovirus infection in immunocompromised adults is similar to that of 2009 H1N1 influenza. J Clin Microbiol 2012;50(3):1061-1063

81 Delangue J, Roca Sanchez Y, Piorkowski G, et al. Viral aetiology influenza like illnesses in Santa Cruz, Bolivia (2010-2012). Virol J 2014;11:35-45 
82 Dia N, Richard V, Kiori D, et al. Respiratory viruses associated with patients older than 50 years presenting with ILI in Senegal, 2009 to 2011. BMC Infect Dis 2014;14:189-194

83 Ju X, Fang Q, Zhang J, Xu A, Liang L, Ke C. Viral etiology of influenza-like illnesses in Huizhou, China, from 2011 to 2013. Arch Virol 2014;159(8):2003-2010

84 Marcone DN, Culasso A, Carballal G, Campos R, Echavarría M. Genetic diversity and clinical impact of human rhinoviruses in hospitalized and outpatient children with acute respiratory infection, Argentina. J Clin Virol 2014;61(4):558-564

85 Pariani E, Martinelli M, Canuti M, et al. Influenza and other respiratory viruses involved in severe acute respiratory disease in northern Italy during the pandemic and postpandemic period (2009-2011). Biomed Res Int 2014;2014:241298

86 Zimmerman RK, Rinaldo CR, Nowalk MP, et al. Influenza and other respiratory virus infections in outpatients with medically attended acute respiratory infection during the 2011-12 influenza season. Influenza Other Respi Viruses 2014;8(4): 397-405

87 Atmar RL, Guy E, Guntupalli KK, et al. Respiratory tract viral infections in inner-city asthmatic adults. Arch Intern Med 1998; 158(22):2453-2459

88 Nicholson KG, Kent J, Ireland DC. Respiratory viruses and exacerbations of asthma in adults. BMJ 1993;307(6910):982-986

89 Xiang Z, Gonzalez R, Xie Z, et al. Human rhinovirus group C infection in children with lower respiratory tract infection. Emerg Infect Dis 2008;14(10):1665-1667

90 Grünberg K, Timmers MC, de Klerk EP, Dick EC, Sterk PJ. Experimental rhinovirus 16 infection causes variable airway obstruction in subjects with atopic asthma. Am J Respir Crit Care Med 1999;160(4):1375-1380

91 Papadopoulos NG, Bates PJ, Bardin PG, et al. Rhinoviruses infect the lower airways. J Infect Dis 2000;181(6):1875-1884

92 Gern JE, Galagan DM, Jarjour NN, Dick EC, Busse WW. Detection of rhinovirus RNA in lower airway cells during experimentally induced infection. Am J Respir Crit Care Med 1997;155(3): 1159-1161

93 Zhu Z, Tang W, Gwaltney JM Jr, Wu Y, Elias JA. Rhinovirus stimulation of interleukin-8 in vivo and in vitro: role of NFkappaB. Am J Physiol 1997;273(4, Pt 1):L814-L824

94 Gern JE, Vrtis R, Grindle KA, Swenson C, Busse WW. Relationship of upper and lower airway cytokines to outcome of experimental rhinovirus infection. Am J Respir Crit Care Med 2000;162(6): 2226-2231

95 Zhu Z, Tang W, Ray A, et al. Rhinovirus stimulation of interleukin6 in vivo and in vitro. Evidence for nuclear factor kappa Bdependent transcriptional activation. J Clin Invest 1996;97(2): 421-430

96 Wark PA, Johnston SL, Bucchieri F, et al. Asthmatic bronchial epithelial cells have a deficient innate immune response to infection with rhinovirus. J Exp Med 2005;201(6):937-947

97 Forbes RL, Gibson PG, Murphy VE, Wark PA. Impaired type I and III interferon response to rhinovirus infection during pregnancy and asthma. Thorax 2012;67(3):209-214

98 Contoli M, Message SD, Laza-Stanca V, et al. Role of deficient type III interferon-lambda production in asthma exacerbations. Nat Med 2006;12(9):1023-1026

99 Durrani SR, Montville DJ, Pratt AS, et al. Innate immune responses to rhinovirus are reduced by the high-affinity $\operatorname{IgE}$ receptor in allergic asthmatic children. J Allergy Clin Immunol 2012;130(2): 489-495

100 Heymann PW, Kennedy JL. Rhinovirus-induced asthma exacerbations during childhood: the importance of understanding the atopic status of the host. J Allergy Clin Immunol 2012;130(6): 1315-1316

101 Beigelman A, Bacharier LB. The role of early life viral bronchiolitis in the inception of asthma. Curr Opin Allergy Clin Immunol 2013; 13(2):211-216
102 Piotrowska Z, Vázquez M, Shapiro ED, et al. Rhinoviruses are a major cause of wheezing and hospitalization in children less than 2 years of age. Pediatr Infect Dis J 2009;28(1):25-29

103 Chung JY, Han TH, Kim SW, Kim CK, Hwang ES. Detection of viruses identified recently in children with acute wheezing. J Med Virol 2007;79(8):1238-1243

104 Jackson DJ, Gangnon RE, Evans MD, et al. Wheezing rhinovirus illnesses in early life predict asthma development in high-risk children. Am J Respir Crit Care Med 2008;178(7):667-672

105 Lemanske RF Jr, Jackson DJ, Gangnon RE, et al. Rhinovirus illnesses during infancy predict subsequent childhood wheezing. J Allergy Clin Immunol 2005;116(3):571-577

106 Kim WK, Gern JE. Updates in the relationship between human rhinovirus and asthma. Allergy Asthma Immunol Res 2012;4(3): 116-121

107 Jackson DJ, Evans MD, Gangnon RE, et al. Evidence for a causal relationship between allergic sensitization and rhinovirus wheezing in early life. Am J Respir Crit Care Med 2012;185(3): 281-285

108 Calışkan M, Bochkov YA, Kreiner-Møller E, et al. Rhinovirus wheezing illness and genetic risk of childhood-onset asthma. N Engl J Med 2013;368(15):1398-1407

109 Seemungal T, Harper-Owen R, Bhowmik A, et al. Respiratory viruses, symptoms, and inflammatory markers in acute exacerbations and stable chronic obstructive pulmonary disease. Am J Respir Crit Care Med 2001;164(9):1618-1623

110 Rohde G, Wiethege A, Borg I, et al. Respiratory viruses in exacerbations of chronic obstructive pulmonary disease requiring hospitalisation: a case-control study. Thorax 2003;58(1): 37-42

111 Ko FW, Ip M, Chan PK, et al. Viral etiology of acute exacerbations of COPD in Hong Kong. Chest 2007;132(3):900-908

112 Perotin JM, Dury S, Renois F, et al. Detection of multiple viral and bacterial infections in acute exacerbation of chronic obstructive pulmonary disease: a pilot prospective study. J Med Virol 2013; 85(5):866-873

113 Kherad O, Kaiser L, Bridevaux PO, et al. Upper-respiratory viral infection, biomarkers, and COPD exacerbations. Chest 2010; 138(4):896-904

114 Sajjan US, Jia Y, Newcomb DC, et al. H. influenzae potentiates airway epithelial cell responses to rhinovirus by increasing ICAM1 and TLR3 expression. FASEB J 2006;20(12):2121-2123

115 Heikkinen T, Chonmaitree T. Importance of respiratory viruses in acute otitis media. Clin Microbiol Rev 2003;16(2):230-241

116 Bulut Y, Güven M, Otlu B, et al. Acute otitis media and respiratory viruses. Eur J Pediatr 2007;166(3):223-228

117 McBride TP, Doyle WJ, Hayden FG, Gwaltney JM Jr. Alterations of the eustachian tube, middle ear, and nose in rhinovirus infection. Arch Otolaryngol Head Neck Surg 1989;115(9):1054-1059

118 Chantzi FM, Papadopoulos NG, Bairamis T, et al. Human rhinoviruses in otitis media with effusion. Pediatr Allergy Immunol 2006;17(7):514-518

119 Madhi SA, Govender N, Dayal K, et al. Bacterial and respiratory viral interactions in the etiology of acute otitis media in HIVinfected and HIV-uninfected South African children. Pediatr Infect Dis J 2015;34(7):753-760

120 Gwaltney JM Jr, Phillips CD, Miller RD, Riker DK. Computed tomographic study of the common cold. N Engl J Med 1994; 330(1):25-30

121 Elkhatieb A, Hipskind G, Woerner D, Hayden FG. Middle ear abnormalities during natural rhinovirus colds in adults. J Infect Dis 1993;168(3):618-621

122 Pitkäranta A, Roivainen M, Blomgren K, et al. Presence of viral and bacterial pathogens in the nasopharynx of otitis-prone children. A prospective study. Int J Pediatr Otorhinolaryngol 2006;70(4): 647-654

123 Pitkäranta A, Arruda E, Malmberg H, Hayden FG. Detection of rhinovirus in sinus brushings of patients with acute community- 
acquired sinusitis by reverse transcription-PCR. J Clin Microbiol 1997;35(7):1791-1793

124 Gwaltney JM Jr, Hendley JO, Phillips CD, Bass CR, Mygind N, Winther B. Nose blowing propels nasal fluid into the paranasal sinuses. Clin Infect Dis 2000;30(2):387-391

125 Falsey AR, Walsh EE, Hayden FG. Rhinovirus and coronavirus infection-associated hospitalizations among older adults. J Infect Dis 2002;185(9):1338-1341

126 Franz A, Adams O, Willems R, et al. Correlation of viral load of respiratory pathogens and co-infections with disease severity in children hospitalized for lower respiratory tract infection. J Clin Virol 2010;48(4):239-245

127 Marcos MA, Esperatti M, Torres A. Viral pneumonia. Curr Opin Infect Dis 2009;22(2):143-147

128 Nascimento-Carvalho CM, Ribeiro CT, Cardoso MR, et al. The role of respiratory viral infections among children hospitalized for community-acquired pneumonia in a developing country. Pediatr Infect Dis J 2008;27(10):939-941

129 Choi SH, Hong SB, Ko GB, et al. Viral infection in patients with severe pneumonia requiring intensive care unit admission. Am J Respir Crit Care Med 2012;186(4):325-332

130 Launes C, de-Sevilla MF, Selva L, Garcia-Garcia JJ, Pallares R, Muñoz-Almagro C. Viral coinfection in children less than five years old with invasive pneumococcal disease. Pediatr Infect Dis J 2012;31(6):650-653

131 García-García ML, Calvo C, Pozo F, Villadangos PA, Pérez-Breña P, Casas I. Spectrum of respiratory viruses in children with community-acquired pneumonia. Pediatr Infect Dis J 2012;31(8): 808-813

132 Miller EK, Bugna J, Libster R, et al. Human rhinoviruses in severe respiratory disease in very low birth weight infants. Pediatrics 2012;129(1):e60-e67

133 Esposito S, Daleno C, Tagliabue C, et al. Impact of rhinoviruses on pediatric community-acquired pneumonia. Eur J Clin Microbiol Infect Dis 2012;31(7):1637-1645

134 Homaira N, Luby SP, Petri WA, et al. Incidence of respiratory virus-associated pneumonia in urban poor young children of Dhaka, Bangladesh, 2009-2011. PLoS ONE 2012;7(2):e32056

135 Guerrier G, Goyet S, Chheng ET, et al. Acute viral lower respiratory tract infections in Cambodian children: clinical and epidemiologic characteristics. Pediatr Infect Dis J 2013;32(1):e8-e13

136 Cho HJ, Shim SY, Son DW, Sun YH, Tchah H, Jeon IS. Respiratory viruses in neonates hospitalized with acute lower respiratory tract infections. Pediatr Int 2013;55(1):49-53

137 Suzuki A, Lupisan S, Furuse Y, et al. Respiratory viruses from hospitalized children with severe pneumonia in the Philippines. BMC Infect Dis 2012;12:267

138 Uršič T, Jevšnik M, Zigon N, et al. Human bocavirus and other respiratory viral infections in a 2-year cohort of hospitalized children. J Med Virol 2012;84(1):99-108

139 Pretorius MA, Madhi SA, Cohen C, et al. Respiratory viral coinfections identified by a 10-plex real-time reverse-transcription polymerase chain reaction assay in patients hospitalized with severe acute respiratory illness-South Africa, 2009-2010. J Infect Dis 2012;206(Suppl 1):S159-S165

140 Lu G, Li J, Xie Z, et al. Human metapneumovirus associated with community-acquired pneumonia in children in Beijing, China. J Med Virol 2013;85(1):138-143

141 Chidlow GR, Laing IA, Harnett GB, et al. Respiratory viral pathogens associated with lower respiratory tract disease among young children in the highlands of Papua New Guinea. J Clin Virol 2012;54(3):235-239

142 Ghani AS, Morrow BM, Hardie DR, Argent AC. An investigation into the prevalence and outcome of patients admitted to a pediatric intensive care unit with viral respiratory tract infections in Cape Town, South Africa. Pediatr Crit Care Med 2012; 13(5):e275-e281
143 Chen YW, Huang YC, Ho TH, Huang CG, Tsao KC, Lin TY. Viral etiology of bronchiolitis among pediatric inpatients in northern Taiwan with emphasis on newly identified respiratory viruses. J Microbiol Immunol Infect 2014;47(2):116-121

144 Antunes H, Rodrigues H, Silva N, et al. Etiology of bronchiolitis in a hospitalized pediatric population: prospective multicenter study. J Clin Virol 2010;48(2):134-136

145 Mansbach JM, Piedra PA, Teach SJ, et al; MARC-30 Investigators. Prospective multicenter study of viral etiology and hospital length of stay in children with severe bronchiolitis. Arch Pediatr Adolesc Med 2012;166(8):700-706

146 Zeng SZ, Xiao NG, Xie ZP, et al. Prevalence of human rhinovirus in children admitted to hospital with acute lower respiratory tract infections in Changsha, China. J Med Virol 2014;86(11): 1983-1989

147 Ouédraogo S, Traoré B, Nene Bi ZA, et al. Viral etiology of respiratory tract infections in children at the pediatric hospital in Ouagadougou (Burkina Faso). PLoS ONE 2014;9(10):e110435

148 Gooskens J, van der Ploeg V, Sukhai RN, Vossen AC, Claas EC, Kroes AC. Clinical evaluation of viral acute respiratory tract infections in children presenting to the emergency department of a tertiary referral hospital in the Netherlands. BMC Pediatr 2014; 14:297-305

149 Qu JX, Gu L, Pu ZH, et al; Beijing Network for Adult CommunityAcquired Pneumonia (BNACAP). Viral etiology of communityacquired pneumonia among adolescents and adults with mild or moderate severity and its relation to age and severity. BMC Infect Dis 2015;15:89-96

150 Seo YB, Song JY, Choi MJ, et al. Etiology and clinical outcomes of acute respiratory virus infection in hospitalized adults. Infect Chemother 2014;46(2):67-76

151 Walker E, Ison MG. Respiratory viral infections among hospitalized adults: experience of a single tertiary healthcare hospital. Influenza Other Respi Viruses 2014;8(3):282-292

152 Drieghe S, Ryckaert I, Beuselinck K, Lagrou K, Padalko E. Epidemiology of respiratory viruses in bronchoalveolar lavage samples in a tertiary hospital. J Clin Virol 2014;59(3):208-211

153 Fica A, Dabanch J, Andrade W, et al. Clinical relevance of rhinovirus infections among adult hospitalized patients. Braz J Infect Dis 2015;19(2):118-124

154 Zhan Y, Yang Z, Chen R, Wang Y, Guan W, Zhao S. Respiratory virus is a real pathogen in immunocompetent community-acquired pneumonia: comparing to influenza like illness and volunteer controls. BMC Pulm Med 2014;14:144-152

155 Jain S, Self WH, Wunderink RG, et al; CDC EPIC Study Team. Community-Acquired Pneumonia Requiring Hospitalization among U.S. Adults. N Engl J Med 2015;373(5):415-427

156 Shah A, Connelly M, Whitaker P, et al. Pathogenicity of individual rhinovirus species during exacerbations of cystic fibrosis. Eur Respir J 2015;45(6):1748-1751

157 Collinson J, Nicholson KG, Cancio E, et al. Effects of upper respiratory tract infections in patients with cystic fibrosis. Thorax 1996;51(11):1115-1122

158 Smyth AR, Smyth RL, Tong CY, Hart CA, Heaf DP. Effect of respiratory virus infections including rhinovirus on clinical status in cystic fibrosis. Arch Dis Child 1995;73(2):117-120

159 Goffard A, Lambert V, Salleron J, et al. Virus and cystic fibrosis: rhinoviruses are associated with exacerbations in adult patients. J Clin Virol 2014;60(2):147-153

160 Ramirez IA, Caverly LJ, Kalikin LM, et al. Differential responses to rhinovirus- and influenza-associated pulmonary exacerbations in patients with cystic fibrosis. Ann Am Thorac Soc 2014;11(4): 554-561 (Erratun: Caverly, Lindsay L [corrected to Caverly, Lindsay J])

161 Garbino J, Gerbase MW, Wunderli W, et al. Respiratory viruses and severe lower respiratory tract complications in hospitalized patients. Chest 2004;125(3):1033-1039 
162 Ison MG, Hayden FG, Kaiser L, Corey L, Boeckh M. Rhinovirus infections in hematopoietic stem cell transplant recipients with pneumonia. Clin Infect Dis 2003;36(9):1139-1143

163 Hassan IA, Chopra R, Swindell R, Mutton KJ. Respiratory viral infections after bone marrow/peripheral stem-cell transplantation: the Christie hospital experience. Bone Marrow Transplant 2003;32(1):73-77

164 Ljungman P, Ward KN, Crooks BN, et al. Respiratory virus infections after stem cell transplantation: a prospective study from the Infectious Diseases Working Party of the European Group for Blood and Marrow Transplantation. Bone Marrow Transplant 2001;28(5):479-484

165 Ghosh S, Champlin R, Couch R, et al. Rhinovirus infections in myelosuppressed adult blood and marrow transplant recipients. Clin Infect Dis 1999;29(3):528-532

166 Milano F, Campbell AP, Guthrie KA, et al. Human rhinovirus and coronavirus detection among allogeneic hematopoietic stem cell transplantation recipients. Blood 2010;115(10):2088-2094

167 Ohrmalm L, Wong M, Aust C, et al. Viral findings in adult hematological patients with neutropenia. PLoS ONE 2012;7(5): e36543

168 Torres JP, Labraña Y, Ibañez C, et al. Frequency and clinical outcome of respiratory viral infections and mixed viral-bacterial infections in children with cancer, fever and neutropenia. Pediatr Infect Dis J 2012;31(9):889-893

169 Seo S, Renaud C, Kuypers JM, et al. Idiopathic pneumonia syndrome after hematopoietic cell transplantation: evidence of occult infectious etiologies. Blood 2015;125(24):3789-3797

170 Campbell AP, Guthrie KA, Englund JA, et al. Clinical outcomes associated with respiratory virus detection before allogeneic hematopoietic stem cell transplant. Clin Infect Dis 2015;61(2): 192-202

171 Longtin J, Winter AL, Heng D, et al. Severe human rhinovirus outbreak associated with fatalities in a long-term care facility in Ontario, Canada. J Am Geriatr Soc 2010;58(10): 2036-2038

172 Valenti WM, Clarke TA, Hall CB, Menegus MA, Shapiro DL. Concurrent outbreaks of rhinovirus and respiratory syncytial virus in an intensive care nursery: epidemiology and associated risk factors. J Pediatr 1982;100(5):722-726

173 Reid AB, Anderson TL, Cooley L, Williamson J, Mcgregor AR. An outbreak of human rhinovirus species $C$ infections in a neonatal intensive care unit. Pediatr Infect Dis J 2011;30(12):1096-1095

174 van Piggelen RO, van Loon AM, Krediet TG, Verboon-Maciolek MA. Human rhinovirus causes severe infection in preterm infants. Pediatr Infect Dis J 2010;29(4):364-365

175 Longtin J, Marchand-Austin A, Winter AL, et al. Rhinovirus outbreaks in long-term care facilities, Ontario, Canada. Emerg Infect Dis 2010;16(9):1463-1465

176 Wald TG, Shult P, Krause P, Miller BA, Drinka P, Gravenstein S. A rhinovirus outbreak among residents of a long-term care facility. Ann Intern Med 1995;123(8):588-593

177 Schoop R, Klein P, Suter A, Johnston SL. Echinacea in the prevention of induced rhinovirus colds: a meta-analysis. Clin Ther 2006; 28(2):174-183

178 Louie JK, Yagi S, Nelson FA, et al. Rhinovirus outbreak in a long term care facility for elderly persons associated with unusually high mortality. Clin Infect Dis 2005;41(2):262-265

179 Hicks LA, Shepard CW, Britz PH, et al. Two outbreaks of severe respiratory disease in nursing homes associated with rhinovirus. J Am Geriatr Soc 2006;54(2):284-289

180 Siegel JD, Rhinehart E, Jackson M, Chiarello L; Health Care Infection Control Practices Advisory Committee. 2007 Guideline for Isolation Precautions: Preventing Transmission of Infectious Agents in Health Care Settings. Am J Infect Control 2007;35(10, Suppl 2):S65-S164

181 Singh M. Heated, humidified air for the common cold. Cochrane Database Syst Rev 2004;(2):CD001728
182 Rotbart HA. Antiviral therapy for enteroviruses and rhinoviruses. Antivir Chem Chemother 2000;11(4):261-271

183 Hayden FG, Herrington DT, Coats TL, et al; Pleconaril Respiratory Infection Study Group. Efficacy and safety of oral pleconaril for treatment of colds due to picornaviruses in adults: results of 2 double-blind, randomized, placebo-controlled trials. Clin Infect Dis 2003;36(12):1523-1532

184 Koenighofer M, Lion T, Bodenteich A, et al. Carrageenan nasal spray in virus confirmed common cold: individual patient data analysis of two randomized controlled trials. Multidiscip Respir Med 2014;9(1):57

185 Sperber SJ, Shah LP, Gilbert RD, Ritchey TW, Monto AS. Echinacea purpurea for prevention of experimental rhinovirus colds. Clin Infect Dis 2004;38(10):1367-1371

186 Turner RB. Ineffectiveness of intranasal zinc gluconate for prevention of experimental rhinovirus colds. Clin Infect Dis 2001; 33(11):1865-1870

187 Kurugöl Z, Akilli M, Bayram N, Koturoglu G. The prophylactic and therapeutic effectiveness of zinc sulphate on common cold in children. Acta Paediatr 2006;95(10):1175-1181

188 Yamaya M, Nishimura H, Hatachi Y, et al. Levofloxacin inhibits rhinovirus infection in primary cultures of human tracheal epithelial cells. Antimicrob Agents Chemother 2012;56(8): 4052-4061

189 Min JY, Jang YJ. Macrolide therapy in respiratory viral infections. Mediators Inflamm 2012;2012:649570

190 Jartti T, Nieminen R, Vuorinen T, et al. Short- and long-term efficacy of prednisolone for first acute rhinovirus-induced wheezing episode. J Allergy Clin Immunol 2015;135(3):691-8.e9

191 Turner RB, Hendley JO. Virucidal hand treatments for prevention of rhinovirus infection. J Antimicrob Chemother 2005;56(5): 805-807

192 Savolainen-Kopra C, Korpela T, Simonen-Tikka ML, et al. Single treatment with ethanol hand rub is ineffective against human rhinovirus-hand washing with soap and water removes the virus efficiently. J Med Virol 2012;84(3):543-547

193 Luby SP, Lu X, Cromeans T, Sharker MA, Kadir MA, Erdman DD. Hand contamination with human rhinovirus in Bangladesh. J Med Virol 2014;86(12):2177-2180

194 Blanco JCG, Core S, Pletneva LM, March TH, Boukhvalova MS, Kajon AE. Prophylactic antibody treatment and intramuscular immunization reduce infectious human rhinovirus 16 load in the lower respiratory tract of challenged cotton rats. Trials Vaccinol 2014;3:52-60

195 Glanville N, Johnston SL. Challenges in developing a cross-serotype rhinovirus vaccine. Curr Opin Virol 2015;11:83-88

196 McLean GR. Developing a vaccine for human rhinoviruses. J Vaccines Immun 2014;2(3):16-20

197 McLean GR, Walton RP, Shetty S, et al. Rhinovirus infections and immunisation induce cross-serotype reactive antibodies to VP1. Antiviral Res 2012;95(3):193-201

198 Yeager CL, Ashmun RA, Williams RK, et al. Human aminopeptidase $\mathrm{N}$ is a receptor for human coronavirus 229E. Nature 1992; 357(6377):420-422

199 Reguera J, Mudgal G, Santiago C, Casasnovas JM. A structural view of coronavirus-receptor interactions. Virus Res 2014;194:3-15

200 Li F. Receptor recognition mechanisms of coronaviruses: a decade of structural studies. J Virol 2015;89(4):1954-1964

201 Hofmann H, Pyrc K, van der Hoek L, Geier M, Berkhout B, Pöhlmann S. Human coronavirus NL63 employs the severe acute respiratory syndrome coronavirus receptor for cellular entry. Proc Natl Acad Sci U S A 2005;102(22):7988-7993

202 Williams RK, Jiang GS, Holmes KV. Receptor for mouse hepatitis virus is a member of the carcinoembryonic antigen family of glycoproteins. Proc Natl Acad Sci U S A 1991;88(13): 5533-5536

203 Huang X, Dong W, Milewska A, et al. HCoV-HKU1 spike protein uses $O$-acetylated sialic acid as an attachment receptor 
determinant and employs HE protein as a receptor-destroying enzyme. J Virol 2015;89(14):7202-7213

204 Gralinski LE, Baric RS. Molecular pathology of emerging coronavirus infections. J Pathol 2015;235(2):185-195

205 Schäfer A, Baric RS, Ferris MT. Systems approaches to Coronavirus pathogenesis. Curr Opin Virol 2014;6:61-69

206 Coleman CM, Liu YV, Mu H, et al. Purified coronavirus spike protein nanoparticles induce coronavirus neutralizing antibodies in mice. Vaccine 2014;32(26):3169-3174

207 Tang XC, Agnihothram SS, Jiao Y, et al. Identification of human neutralizing antibodies against MERS-CoV and their role in virus adaptive evolution. Proc Natl Acad Sci U S A 2014;111(19): E2018-E2026

208 van den Brand JM, Smits SL, Haagmans BL. Pathogenesis of Middle East respiratory syndrome coronavirus. J Pathol 2015;235(2): 175-184

209 Totura AL, Baric RS. SARS coronavirus pathogenesis: host innate immune responses and viral antagonism of interferon. Curr Opin Virol 2012;2(3):264-275

210 Schmidt OW, Kenny GE. Immunogenicity and antigenicity of human coronaviruses 229E and OC43. Infect Immun 1981; 32(3):1000-1006

211 McIntosh K, Dees JH, Becker WB, Kapikian AZ, Chanock RM. Recovery in tracheal organ cultures of novel viruses from patients with respiratory disease. Proc Natl Acad Sci U S A 1967;57(4): 933-940

212 McIntosh K, Ellis EF, Hoffman LS, Lybass TG, Eller JJ, Fulginiti VA. Association of viral and bacterial respiratory infection with exacerbations of wheezing in young asthmatic children. Chest 1973;63(Suppl):43S

213 Falsey AR, McCann RM, Hall WJ, et al. The "common cold" in frail older persons: impact of rhinovirus and coronavirus in a senior daycare center. J Am Geriatr Soc 1997;45(6):706-711

214 Dijkman R, Jebbink MF, El Idrissi NB, et al. Human coronavirus NL63 and 229E seroconversion in children. J Clin Microbiol 2008; 46(7):2368-2373

215 Drosten C, Günther S, Preiser W, et al. Identification of a novel coronavirus in patients with severe acute respiratory syndrome. N Engl J Med 2003;348(20):1967-1976

216 Vabret A, Mourez T, Dina J, et al. Human coronavirus NL63, France. Emerg Infect Dis 2005;11(8):1225-1229

217 Arden KE, Nissen MD, Sloots TP, Mackay IM. New human coronavirus, HCoV-NL63, associated with severe lower respiratory tract disease in Australia. J Med Virol 2005;75(3):455-462

218 van der Hoek L, Pyrc K, Jebbink MF, et al. Identification of a new human coronavirus. Nat Med 2004;10(4):368-373

219 Esper F, Weibel C, Ferguson D, Landry ML, Kahn JS. Coronavirus HKU1 infection in the United States. Emerg Infect Dis 2006;12(5): 775-779

220 Esper F, Weibel C, Ferguson D, Landry ML, Kahn JS. Evidence of a novel human coronavirus that is associated with respiratory tract disease in infants and young children. J Infect Dis 2005;191(4): 492-498

221 Talbot HK, Shepherd BE, Crowe JE Jr, et al. The pediatric burden of human coronaviruses evaluated for twenty years. Pediatr Infect Dis J 2009;28(8):682-687

222 Vijgen L, Keyaerts E, Lemey P, et al. Circulation of genetically distinct contemporary human coronavirus OC43 strains. Virology 2005;337(1):85-92

223 Cheng VC, Lau SK, Woo PC, Yuen KY. Severe acute respiratory syndrome coronavirus as an agent of emerging and reemerging infection. Clin Microbiol Rev 2007;20(4):660-694

224 Memish ZA, Cotten M, Meyer B, et al. Human infection with MERS coronavirus after exposure to infected camels, Saudi Arabia, 2013. Emerg Infect Dis 2014;20(6):1012-1015

225 Saad M, Omrani AS, Baig K, et al. Clinical aspects and outcomes of 70 patients with Middle East respiratory syndrome coronavirus infection: a single-center experience in Saudi Arabia. Int J Infect Dis 2014;29:301-306

226 Assiri A, McGeer A, Perl TM, et al; KSA MERS-CoV Investigation Team. Hospital outbreak of Middle East respiratory syndrome coronavirus. N Engl J Med 2013;369(5):407-416

227 Memish ZA, Cotten M, Watson SJ, et al. Community case clusters of Middle East respiratory syndrome coronavirus in Hafr AlBatin, Kingdom of Saudi Arabia: a descriptive genomic study. Int J Infect Dis 2014;23:63-68

228 Centers for Disease Control and Prevention. CDC announces second imported case of Middle East Respiratory Syndrome (MERS) in the United States [press release]. Available at: http:// www.cdc.gov/media/releases/2014/p0512-US-MERS.html. Published May 12, 2014

229 Centers for Disease Control and Prevention. CDC telebriefing: updates on Middle East Respiratory Syndrome Coronavirus (MERS-CoV) investigation in the United States. Available at: http://www.cdc.gov/media/releases/2014/t0517-mers.html. Published May 17, 2014. Updated May 19, 2014

230 Atmar R, Greenberg SB. Respiratory viral infections. In: Jerome K, ed. Lennette's Laboratory Diagnosis of Viral Infections, 4th ed. New York: Informa Healthcare; 2010:246-271

231 Vabret A, Mouthon F, Mourez T, Gouarin S, Petitjean J, Freymuth F. Direct diagnosis of human respiratory coronaviruses $229 \mathrm{E}$ and OC43 by the polymerase chain reaction. J Virol Methods 2001; 97(1-2):59-66

232 Cao Z, Liu L, Du L, et al. Potent and persistent antibody responses against the receptor-binding domain of SARS-CoV spike protein in recovered patients. Virol J 2010;7:299

233 Adachi D, Johnson G, Draker R, et al. Comprehensive detection and identification of human coronaviruses, including the SARSassociated coronavirus, with a single RT-PCR assay. J Virol Methods 2004;122(1):29-36

234 Walsh EE, Shin JH, Falsey AR. Clinical impact of human coronaviruses 229E and OC43 infection in diverse adult populations. $\mathrm{J}$ Infect Dis 2013;208(10):1634-1642

235 Reusken C, Mou H, Godeke GJ, et al. Specific serology for emerging human coronaviruses by protein microarray. Euro Surveill 2013; 18(14):20441

236 Che XY, Qiu LW, Pan YX, et al. Sensitive and specific monoclonal antibody-based capture enzyme immunoassay for detection of nucleocapsid antigen in sera from patients with severe acute respiratory syndrome. J Clin Microbiol 2004;42(6):2629-2635

237 Zhao G, Du L, Ma C, et al. A safe and convenient pseudovirusbased inhibition assay to detect neutralizing antibodies and screen for viral entry inhibitors against the novel human coronavirus MERS-CoV. Virol J 2013;10:266

238 Azhar EI, El-Kafrawy SA, Farraj SA, et al. Evidence for camel-tohuman transmission of MERS coronavirus. N Engl J Med 2014; 370(26):2499-2505

239 Gerna G, Campanini G, Rovida F, et al. Genetic variability of human coronavirus OC43-, 229E-, and NL63-like strains and their association with lower respiratory tract infections of hospitalized infants and immunocompromised patients. J Med Virol 2006; 78(7):938-949

240 Gerna G, Percivalle E, Sarasini A, et al. Human respiratory coronavirus HKU1 versus other coronavirus infections in Italian hospitalised patients. J Clin Virol 2007;38(3):244-250

241 Ebihara T, Endo R, Ma X, Ishiguro N, Kikuta H. Detection of human coronavirus NL63 in young children with bronchiolitis. J Med Virol 2005;75(3):463-465

242 Vabret A, Dina J, Gouarin S, et al. Human (non-severe acute respiratory syndrome) coronavirus infections in hospitalised children in France. J Paediatr Child Health 2008;44(4):176-181

243 Wu PS, Chang LY, Berkhout B, et al. Clinical manifestations of human coronavirus NL63 infection in children in Taiwan. Eur J Pediatr 2008;167(1):75-80 
244 Peiris JS, Yuen KY, Osterhaus AD, Stöhr K. The severe acute respiratory syndrome. N Engl J Med 2003;349(25):2431-2441

245 Ksiazek TG, Erdman D, Goldsmith CS, et al; SARS Working Group. A novel coronavirus associated with severe acute respiratory syndrome. N Engl J Med 2003;348(20):1953-1966

246 Milne-Price S, Miazgowicz KL, Munster VJ. The emergence of the Middle East respiratory syndrome coronavirus. Pathog Dis 2014; 71(2):121-136

247 Ajlan AM, Ahyad RA, Jamjoom LG, Alharthy A, Madani TA. Middle East respiratory syndrome coronavirus (MERS-CoV) infection: chest CT findings. AJR Am J Roentgenol 2014;203(4):782-787

248 Gogna A, Tay KH, Tan BS. Severe acute respiratory syndrome: 11 years later-a radiology perspective. AJR Am J Roentgenol 2014;203(4):746-748

249 Cunha CB, Opal SM. Middle East respiratory syndrome (MERS): a new zoonotic viral pneumonia. Virulence 2014;5(6):650-654

250 Wong SS, Yuen KY. The management of coronavirus infections with particular reference to SARS. J Antimicrob Chemother 2008; 62(3):437-441

251 Frausto SD, Lee E, Tang H. Cyclophilins as modulators of viral replication. Viruses 2013;5(7):1684-1701

252 Falzarano D, de Wit E, Martellaro C, Callison J, Munster VJ, Feldmann $\mathrm{H}$. Inhibition of novel $\beta$ coronavirus replication by a combination of interferon- $\alpha 2 b$ and ribavirin. Sci Rep 2013; 3:1686

253 Khalid M, Al Rabiah F, Khan B, Al Mobeireek A, Butt TS, Al Mutairy E. Ribavirin and interferon- $\alpha 2 b$ as primary and preventive treatment for Middle East respiratory syndrome coronavirus: a preliminary report of two cases. Antivir Ther 2015;20(1):87-91

254 de Wilde AH, Jochmans D, Posthuma CC, et al. Screening of an FDA-approved compound library identifies four small-molecule inhibitors of Middle East respiratory syndrome coronavirus replication in cell culture. Antimicrob Agents Chemother 2014; 58(8):4875-4884

255 Kindrachuk J, Ork B, Hart BJ, et al. Antiviral potential of ERK/MAPK and PI3K/AKT/mTOR signaling modulation for Middle East respiratory syndrome coronavirus infection as identified by temporal kinome analysis. Antimicrob Agents Chemother 2015;59(2): 1088-1099

256 Chu CM, Cheng VC, Hung IF, et al; HKU/UCH SARS Study Group. Role of lopinavir/ritonavir in the treatment of SARS: initial virological and clinical findings. Thorax 2004;59(3):252-256

257 Vincent MJ, Bergeron E, Benjannet S, et al. Chloroquine is a potent inhibitor of SARS coronavirus infection and spread. Virol J 2005; 2:69

258 Al-Tawfiq JA, Memish ZA. Middle East respiratory syndrome coronavirus: epidemiology and disease control measures. Infect Drug Resist 2014;7:281-287
259 Graham RL, Donaldson EF, Baric RS. A decade after SARS: strategies for controlling emerging coronaviruses. Nat Rev Microbiol 2013;11(12):836-848

260 Maltezou HC, Tsiodras S. Middle East respiratory syndrome coronavirus: implications for health care facilities. Am J Infect Control 2014;42(12):1261-1265

261 Mou H, Raj VS, van Kuppeveld FJ, Rottier PJ, Haagmans BL, Bosch $B J$. The receptor binding domain of the new Middle East respiratory syndrome coronavirus maps to a 231-residue region in the spike protein that efficiently elicits neutralizing antibodies. J Virol 2013;87(16):9379-9383

262 Channappanavar R, Zhao J, Perlman S. T cell-mediated immune response to respiratory coronaviruses. Immunol Res 2014; 59(1-3):118-128

263 Ma C, Wang L, Tao X, et al. Searching for an ideal vaccine candidate among different MERS coronavirus receptor-binding fragmentsthe importance of immunofocusing in subunit vaccine design. Vaccine 2014;32(46):6170-6176

264 Ying T, Du L, Ju TW, et al. Exceptionally potent neutralization of Middle East respiratory syndrome coronavirus by human monoclonal antibodies. J Virol 2014;88(14):7796-7805

$265 \mathrm{Ma} \mathrm{C}$, Li Y, Wang L, et al. Intranasal vaccination with recombinant receptor-binding domain of MERS-CoV spike protein induces much stronger local mucosal immune responses than subcutaneous immunization: Implication for designing novel mucosal MERS vaccines. Vaccine 2014;32(18):2100-2108

266 Zhang N, Tang J, Lu L, Jiang S, Du L. Receptor-binding domainbased subunit vaccines against MERS-CoV. Virus Res 2015; 202:151-159

267 Ohnuma K, Haagmans BL, Hatano R, et al. Inhibition of Middle East respiratory syndrome coronavirus infection by anti-CD26 monoclonal antibody. J Virol 2013;87(24):13892-13899

268 Mair-Jenkins J, Saavedra-Campos M, Baillie JK, et al; Convalescent Plasma Study Group. The effectiveness of convalescent plasma and hyperimmune immunoglobulin for the treatment of severe acute respiratory infections of viral etiology: a systematic review and exploratory meta-analysis. J Infect Dis 2015;211(1): 80-90

269 Cheng VC, Chan JF, To KK, Yuen KY. Clinical management and infection control of SARS: lessons learned. Antiviral Res 2013; 100(2):407-419

270 Agnihothram S, Gopal R, Yount BL Jr, et al. Evaluation of serologic and antigenic relationships between middle eastern respiratory syndrome coronavirus and other coronaviruses to develop vaccine platforms for the rapid response to emerging coronaviruses. J Infect Dis 2014;209(7):995-1006

271 Sampathkumar P. Middle East respiratory syndrome: what clinicians need to know. Mayo Clin Proc 2014;89(8):1153-1158 